\title{
A Vision for Malaysian and Other ASEAN Researchers to Contribute to the International Agency Theory-based Literature
}

\author{
Philip Sinnadurai
}

\begin{abstract}
Manuscript type: Review paper

Research aims: This paper offers Southeast Asian researchers, particularly those from ASEAN, a vision to contribute to international agency theory literature.

Design/Methodology/Approach: Most of the studies reviewed were identified during the author's preparation for this paper which involves Malaysia.

Research findings: Three research streams to which Malaysian researchers can contribute are: political connections, family companies and corporate recovery. The socio-political contexts that have resulted in Malaysia being a suitable environment are also discussed. This paper identifies gaps in the literature; it accumulates arguments defining why the Malaysian setting is apposite and it also offers research design suggestions for Malaysians and researchers from Indonesia, the Philippines and Thailand, with some defining differences, to follow.
\end{abstract}

\footnotetext{
Philip Sinnadurai is a Lecturer at the Department of Accounting and Corporate Governance, Faculty of Business and Economics, Macquarie University, NSW 2109, Australia. Email: philip. sinnadurai@mq.edu.au

I am grateful to Professor Susela Devi for inviting me to write this paper. I am also thankful to workshop participants at UNITAR International University, Malaysia and Universiti Teknologi MARA, Malaysia for their feedback at presentations of the material used to develop this paper. I would also like to express my appreciation to Graeme Harrison and Dedi Muhammad Siddiq for their comments and members of the editorial board and two anonymous reviewers for their constructive comments and guidance.
}

https://doi.org/10.22452/ajba.vol11no2.1 
Theoretical contributions/Originality: The outcome drawn from this paper assists Malaysian researchers in utilising the agency based theory to approach various topic selections and executions. The comparisons and contrasts made between Malaysia and the other three ASEAN countries may further motivate researchers of the ASEAN region to engage agency theory as a base for their research.

Research limitation: A limitation to this paper is that the boundaries between the proposed categories of shareholder political connections are blurred.

Keywords: Agency Theory, ASEAN, Malaysia, Review Paper JEL Classification: G31, G33, G38, M41

\section{Introduction}

Agency theory regards a company as a "nexus of contracts" between principals and agents. A "contract" is any arrangement whether expressed or implied, in which parties have reciprocal obligations to each other. In such contracts, principals delegate decision-making authorities to their agents to act on their behalf. However, even in contracts, all parties are assumed to act in their self-interests, possibly to the detriment of other stakeholders (Jensen \& Meckling, 1976).

In business settings characterised by the separation of management and ownership, the main contract is between managers (agents) and shareholders (principals). The interests of these parties are not always aligned thereby generating managerial incentives to pursue policies which are inconsistent with shareholders' wealth maximisation. Some examples of dysfunctional behaviour include excessive perquisite consumption and overinvestment (Richardson, 2006; Yermack, 2006). These practices can result in a decrease in value and the "residual loss" is borne by both the principals and the agents. Principals tend to anticipate such dysfunctional behaviour and so for price protection purposes, the agents' remuneration is adjusted. In this regard, both the principals and the agents have the incentive to institute agency mechanisms (also referred to as "corporate governance mechanisms") so as to re-align the parties' interests and to reduce residual loss (Jensen \& Meckling, 1976).

There are many types of agency mechanisms. Some are external to the company and they serve as a natural feature of the product market. For example, highly competitive industries have many incumbents in providing relatively homogeneous products. In such industries, disclosures made by one player may inform others about demand-side 
factors throughout the entire product market (Ali, Klasa \& Yeung, 2014). Another type of agency mechanism is those imposed by regulators. An example of this type of agency mechanism is the requirement for financial statements to be subjected to an independent audit. Management is aware that its accrual policy choices must satisfy the auditor. Hence, management is discouraged from making accrual policy choices opportunistically (Becker, De Fond, Jiambalvo, \& Subramaniam, 1998). A third category of agency mechanism is those implemented by management. For example, independent directors are included on boards of directors because independent directors are more objective monitors of management (Coles, Daniel, \& Naveen, 2008).

No combination of agency mechanisms could fully eliminate the residual loss. This is true of all three categories of agency mechanisms and illustrated with respect to the three aforementioned examples. Firstly, since no two products are identical, there would be a limit to the extent to which, in a competitive product market, disclosure by one player will reveal demand-side factors across the entire industry (Ali et al., 2014). Secondly, independent auditors lack the management's intimate familiarity with a company's business, hence they are unable to check every transaction and accounting policy (Becker et al., 1998). Thirdly, independent directors may also be acting as directors for several companies, therefore the quality of monitoring they imposed on each company may be questionable (Coles et al., 2008).

Agency theory-based research seeks to improve the understanding of the effectiveness of agency mechanisms and how its effectiveness differs, depending on settings. This review paper explores several gaps in the literature to which Malaysian research could contribute. Research (Sinnadurai, 2016; Heng \& Sieh, 2004; Gomez \& de Micheaux, 2017) has investigated whether corporate political connections constitute an agency cost or an agency mechanism. Research (Sinnadurai, 2016) has also noted that Malaysian firms have many political connections and different types of political connections. In this context, there are also family companies which may carry a different type of agency problem that differs from non-family companies. Hence, the magnitude of agency costs and the efficacy of agency mechanisms may differ vastly. Malaysia is well-positioned to produce evidence that supports this observation. This is because Malaysia has a high percentage of family companies as well as different types of family companies. In fact, these family companies in Malaysia can be distinguished according to whether they are Nanyang or non-Nanyang family companies and also the extent 
to which they employ professional management (Heng \& Sieh, 2004; Gomez \& de Micheaux, 2017).

In Malaysia, the magnitude of the agency costs and the efficacy of agency mechanisms may also differ between distressed and nondistressed companies (Rosner, 2003). Distressed companies face different costs and benefits of accrual-based management versus real earnings management (Zang, 2012). One feature of the Malaysian institution setting is the Practice Note 17 which is a stock exchange listing rule that imposes extra disclosure requirements on distressed companies. These disclosures may be used to predict corporate recovery and more accurately, for modelling the relative costs and benefits as well as for accruals management versus real earnings management for distressed companies.

Shifting to the other countries situated in the Association of Southeast Asian Nations (ASEAN), it can be noted that there are many institutional similarities between Malaysia and her neighbours elsewhere. In this regard, the broad suggestions made in this review paper may be applicable to other countries in the region. However, researchers from neighbouring countries should be cognisant of the fundamental institutional differences (between their countries and Malaysia) while conducting agency theory-based research.

The remainder of this review paper is structured as follows. Section 2 presents suggestions for Malaysian researchers to contribute to the literature on political connections and family companies. Section 3 articulates suggestions for Malaysians to utilise Practice Note 17, a unique institutional feature, so as to contribute to literature on financially distressed companies. Section 4 extends the coverage by making preliminary suggestions for agency theory-based researchers from Indonesia, the Philippines and Thailand and Section 5 concludes. The studies discussed in the sections about Malaysia were identified via three principal modes: The first mode is preparation that I have conducted for workshops delivered at Malaysian universities, for staff and doctoral students, about key papers in my research areas of interest. The second mode is feedback from referees and seminar participants, obtained when Sinnadurai (2016) and Shayan Nia, Sinnadurai, MohdSanusi and Hermawan (2017) were working papers. The third mode is feedback from interactions with Dynaquest Sendirian Berhad and the Malaysian Institute of Corporate Governance. The studies discussed in the sections about Indonesia, the Philippines and Thailand were 
identified via Internet searches, using "Chinese companies" "political connections" and "state-owned enterprises" as keywords.

\section{Suggestions for Malaysian Research into Political Connections and Family Companies}

This section begins by presenting a new approach for operationalising the theoretical definitions of "corporate governance" and "corporate governance quality" in Malaysia. The section proceeds by discussing two different streams of agency theory-based literature, to which Malaysian researchers could contribute by using the new approach.

\subsection{Suggestion for a New Approach to Operationalising Corporate Governance Quality in Malaysia}

Theoretical definitions of corporate governance quality are generally based on Jensen and Meckling's (1976) costly contracting view of the firm but corporate governance has been defined by Shleifer and Vishny (1997) as the actions taken by providers of finance to ensure that they achieve an adequate return on investment. According to this definition, corporate governance quality would be the extent to which investors' actions successfully reduce agency costs and achieve an adequate return on investment. Since Bhagat, Bolton and Romano (2008) viewed corporate governance as a set of mechanism which prompts managers to act in shareholders' interests, the consequential definition of corporate governance quality would thus be the extent to which these mechanisms are successful. Bhagat et al. (2008) also argued that the boards of directors are an integral component of corporate governance.

Typical Anglo-American approaches to operationalising corporate governance quality tend to refer to the characteristics of the board of directors. ${ }^{1}$ Board characteristics that have been examined include board size (Boone, Field, Karpoff, \& Raheja, 2007; Coles et al., 2008), separation of Chief Executive Officer (CEO) and board chair (Daily \& Dalton, 1997), board independence (Boone et al., 2007; Coles et al., 2008), board experience (Mangena \& Pike, 2005; Vafeas, 2005), board education (Yang

\footnotetext{
1 Anglo-American studies have also examined other corporate governance mechanisms. Notably, an index of corporate governance quality frequency used, compiled by Gompers, Ishii and Metrick (2003), is based on the extent to which a company's constitution protects shareholders' rights.
} 
\& Krishnan, 2005), frequency of committee meetings (Baxter \& Cotter, 2009) and the extent to which the board is subjected to CEO capture (Coles, Daniel \& Naveen, 2014).

Most Malaysian researches (Haron, Jantan, \& Pheng, 2005; Abdul Wahab, How, \& Verhoeven, 2007; Che Haat, Abdul Rahman, \& Mahenthiran, 2008; Ponnu, 2008; Goh, Rasli, \& Khan, 2014) use AngloAmerican approaches to operationalise corporate governance quality. For instance, Haron et al. (2005) investigated compliance with the listing requirements related to audit committees. Their results indicate a high level of compliance. In Abdul Wahab et al. (2007), Che Haat et al. (2008), Ponnu (2008) and Goh et al. (2014), the association between corporate governance quality was measured via indicators specified in the Malaysian Code of Corporate Governance, particularly board independence and the separation of CEO and board chair and firm performance. The results drawn from Abdul Wahab et al. (2007) and Che Haat et al. (2008) suggest that there is a positive association. However, the results of Ponnu (2008) and Goh et al. (2014) suggest no association at all. Likewise, Hashim and Devi (2008) documented no evidence that board independence and separation of CEO and board chair constrained opportunistic accruals management. Bliss and Gul (2012) also documented evidence of a negative association between interest rates and corporate governance quality for politically connected companies. They classified "high corporate governance quality" companies which separate the roles of CEO and board chairs and companies, had a larger percentage of independent directors on the audit committee. Measuring the outcome via an index based on the Malaysian Code of Corporate Governance, Ramly (2012) also produced evidence showing a negative association between the cost of equity capital and corporate governance quality.

Based on the above, it is concluded that the Anglo-American influence on the Malaysian regulatory régime may have prompted Malaysian researchers to measure corporate governance quality via board characteristics. The Malaysian Code of Corporate Governance makes extensive reference to board characteristics as hallmarks of sound monitoring. Further to this, financial accounting within Malaysia has also been observed to be largely British influenced (Saudagaran \& Diga, 2000; Vithiatharan \& Gomez, 2014). This implies that the AngloAmerican influence did not emerge out of the blue but had instead, arose due to Malaysia's past as a former British colony. It had prompted Malaysia to adopt the laissez-faire economics elements for approaching its economic development (Gomez, 2009). 
The mixed findings derived from the studies above may be attributed to the fact that Anglo-American approaches may have diminished relevance in Malaysia. It is possible that the boards of directors in Malaysian companies could be a less important corporate governance mechanism. In the family companies existing in Malaysia, the controlling family is likely to "capture" the board even though some non-family members would be serving on the board (Yeung, 2006; Coles et al., 2014). It appears that a more suitable approach for Malaysia would be to emphasise on the management team. This is because a "strong" management would act to maximise shareholders' wealth even when the management and shareholders' interests diverge (Hu \& Kumar, 2004). One Malaysian study done by Fung, Gul and Radhakrishnan (2015) examined board and management professionalism as indicators of corporate governance quality. Their results suggest that for politically connected companies, the higher scores noted for board and management professionalism (measured via the degree of formal education and experience) ameliorates share price impacts of negative macroeconomic news. In this regard, subsequent Malaysian research could follow Fung et al. (2015) by using different management characteristics to indicate corporate governance quality. In addition, Malaysian researchers could also use local sources of data to construct country-specific proxies for theoretical constructs such as management strengths. This step would respond to the call for corporate governance researchers from developing countries to adapt their research designs so as to accommodate unique institutional features (Claessens \& Fan, 2002; Claessens \& Yurtoglu, 2013). ${ }^{2}$

Further measures of corporate governance quality in Malaysia should also acknowledge auditor quality. In family-dominated Malaysian companies, minority shareholders are aware that the management is insulated from the disciplinary forces of the markets for managerial labour and corporate control (Demsetz \& Lehn, 1985; Wang, 2006; Ismail \& Sinnadurai, 2012). Minority shareholders of family-dominated companies, may be concerned that family members who make up the dominant block of the shareholders, have the incentive to suppress proprietary information from the board of directors because disclosures could damage the companies' competitiveness and the family's wealth (Goh et al., 2014). In this regard, minority shareholders may place more

\footnotetext{
${ }^{2}$ For example, some Malaysian researches have used data from Dynaquest Sendirian Berhad, a local firm of investment consultants (Ismail and Sinnadurai, 2012; Sinnadurai, 2016).
} 
reliance on the financial statements which can be used as an alternative monitoring mechanism. This would increase the demand for financial statements to be subjected to high quality audits (Claessens \& Fan, 2002; Goh et al., 2014).

\subsection{Political Connections}

\subsubsection{Background to Political Connections in Malaysia}

Successive Malaysian governments, over the years, have fused two different ideologies into their approach towards economic and social development. The first ideology, the "developmental state", is characterised by high-level government interventions in the corporate sector which aim to facilitate gross domestic product growth and distribution. Dimensions of the developmental state such as publicprivate partnerships and the distribution of national wealth to sections of society deemed in need are embraced by the Malaysian government. The second ideology is the laissez-faire economics upon which the dimensions utilised to spur this ideology encompass privatisations and the stock markets (Gomez, 2009; Gomez, Fisal, Padmanabhan, \& Tajuddin, 2018).

The fusion of these two ideologies is directed towards achieving two different objectives. The first objective is for social restructuring. In the social dimension of Malaysia, a recurring theme prominent in Malaysian history is the disparity in wealth and political power, between the bumiputera (Malays and indigenous Malaysians) and the Chinese, Indians and other ethnic minorities. Historically, the Chinese have been urban dwellers generating most of the nation's wealth and economic output via business enterprises. Conversely, the bumiputera have principally been poor rural dwellers with control over the nation's politics (Sinnadurai, 2016). Tensions between the two ethnic groups erupted in race riots in 1969. Hence, in 1970, the Malaysian government embarked on its "New Economic Policy" (NEP) which was aimed at redressing such imbalances. The objectives were to eradicate poverty and to restructure society so as to eliminate the association between ethnicity and economic function. The National Development Plan, formulated in 1990 was espoused to maintain the objectives of the NEP during the era of 1991-2000 (Siddiquee, 2002). The other objective of the National Development Plan was to mix these ideologies for nationbuilding and to increase the overall size of national wealth (Gomez, 
2009; Gomez et al., 2018). As a result of the government fusing these two ideologies, Malaysia has blurred the boundaries between the public and the private sectors, through an abundance of political connections as well as different types of political connections. This institutional setting is apposite for contributing to agency theory-based literature on political connections.

During the NEP era (1970-1989), developmental state policies also escalated. Government-linked investment companies (GLICs) were formed as trusts to manage share portfolios of listed Malaysian companies for the purpose of the distribution of national wealth to the bumiputera and other segments of society targeted for assistance. ${ }^{3}$ The GLICs constitute the principal institutional investors of Malaysia. They also held shares in government-linked companies (GLCs) some of which are listed on the Malaysian Stock Exchange and managed with dual goals of maximising shareholders' wealth and implementing government policies (Gomez, 2009; Gomez et al., 2018).

Privatisations which were designed to achieve social restructuring became a legacy of the era of the first Mahathir government, 1981-2003. During this era, state enterprises were privatised to Malay capitalists with the government retaining influence as a trustee. The privatisations occurred primarily via private placements with prescribed portions of shares to be reserved for bumiputera investors and other Malaysian institutions. During this era, the Malaysian government retained substantial ownership and influence over the policies of the privatised corporations such as the Malaysian Airline System and Sports Toto, a gaming company (Salleh, 1999).

Under Mahathir, the Malaysian government also cultivated protégés from the arms of the dominant United Malays National Organisation (UMNO), principally Anwar Ibrahim and Daim Zainuddin. These protégés were appointed as advisers to corporations as an effort to guide the business models to be friendly to the government's plans for economic and social development. The relationships between corporations and Anwar Ibrahim and/or Daim Zainuddin enabled these companies to secure nation-building projects (Fraser, Zhang, \& Derashid, 2006). Following Anwar and Daim's fallout with Mahathir in 1998 and 2001, the patronised companies also suffered declines in their financial performances (Gomez, 2009). They also performed poorly

\footnotetext{
${ }^{3}$ Other targeted beneficiaries include members of the armed services and their families and Muslims, receiving financial support for their pilgrimage to Mecca (Gomez, 2009).
} 
during the period of the global financial crisis (GFC) of 2008-2009 (Vithiatharan \& Gomez, 2014).

In 1983, the Mahathir government implemented the "Malaysia Incorporated" programme. It involved the close cooperation between public and private sectors as a means to fuel the economic and social development of the country. The programme had been designed to deliver complementary benefits to the respective sectors, where the private sectors would experience increased growth and profitability and the public sector would accrue more fiscal revenue and an increased attainment of its missions (Siddiquee, 2002). This inter-sectoral cooperation also had other dimensions such as government entities depending on the private sector for political donations and the private sector entrepreneurs depending on the government for bumiputera employment and subscriptions to equity raisings (which are legal requirements) as well as licensing and trade permits. Malaysia was characterised by a high rate of politician involvement in private business and business people in politics (Salleh, 1999).

The "Malaysia Incorporated" programme also involved "mega projects" for public infrastructure construction, one of which was the creation and distribution of national Malaysian cars. This was managed by state-owned Heavy Industries Commission of Malaysia (HICOM) which promoted links between Malaysian companies and foreign venturers to produce and distribute national cars. In 1985, HICOM entered into a joint venture with Mitsubishi to create the Proton Saga, a Malaysian car. Following this, the listed company Edaran Otomobil Nasional Berhad (EON) was created to distribute the Proton Saga. HICOM also orchestrated a joint venture between Citroen and the listed Malaysian company, Diversified Resources Berhad (DRB) to create and distribute new national cars. It then merged with HICOM in 1996 to become the new, listed company of DRB-Hicom Berhad (Siddiquee, 2006; Gomez, 2009). Other privatised infrastructure projects were also pursued via inter-sectoral cooperations including the construction of the North-South highway, ports, power generation plants and a light rail network (Salleh, 1999). After the Asian financial crisis of 1997-1998, one remedial response of the Mahathir government was to renationalise mega projects, including the Bakun Dam, Malaysian Airline System, Celcom (a telecommunications provider) and UEM (the operator of tolls for the North-South highway) (Gomez, 2009).

The governance of the GLCs reflect a marriage between the ideologies of the developmental state and the laissez-faire economics. In 
response to allegations of inefficiencies occurring within these corporations, voiced after the Asian Financial Crisis, the Malaysian government then implemented the GLC Transformation Programme in 2005. The recommendation was towards corporatisation and this include: enhancing the effectiveness of the boards of directors, improving the monitoring of institutional shareholders and intensifying performance management (Putrajaya Committee on GLC High Performance, 2005).

\subsubsection{Summary of the International and Malaysian Empirical Evidence Regarding Political Connections}

There is considerable empirical evidence about political connections of companies in various non-Malaysian studies. For instance, using data from a range of countries, Faccio (2006) investigated the characteristics of countries where political connections were prevalent. It was observed that political connections were more pervasive in countries that do not ameliorate politicians' conflicts of interests. The results also suggest that political connections were value-adding for shareholders. In another study, using data from Indonesia, Leuz and Oberholzer-Gee (2006) found that during President Suharto's term, companies that were close to the President were less likely to utilise foreign sources of public finance. This is because the government provided domestic support. The results also indicate that companies that had been close to President Suharto also suffered in performance during President Abdurrahman Wahid's term. This is because the financial support for companies associated with the former presidents were reduced. Charumilind, Kali and Wiwattanakantang (2006) investigated the association between Thai companies' access to bank credits and business connections, prior to the Asian financial crisis. Their findings suggest that during the precrisis era, companies with business connections had preferential debt access. In the study conducted by Boubakri, Guedhami, Mishra and Saffar (2012) which used data from a range of countries to examine whether the cost of equity capital differs between politically connected and non-politically connected companies, it was revealed that politically connected companies have lower costs of equity capital. Using data from the United States, Houston, Jiang, Lin and Ma (2014) documented evidence which showed that politically connected companies enjoyed lower costs of private debts than non-politically connected companies. The findings further indicate that the lower interest rates were attributed to politically connected companies having lower operating risks. 
There are considerable extant agency theory-based empirical literature (Johnson \& Mitton, 2003; Fraser et al., 2006; Gul, 2006; Bliss \& Gul, 2012; Mitchell \& Joseph, 2010; Fung et al., 2015; Tee, Gul, Foo, \& Chee, 2017) on political connections. In the Malaysian context, Johnson and Mitton (2003) documented evidence which showed that politically connected Malaysian companies underperformed their counterparts during the era of external economic shock. They however, outperformed their counterparts during the era of government-imposed restrictions of capital flows. These findings did not extend to companies that were connected to an ousted politician. Fraser et al. (2006) also documented evidence which showed that in Malaysia, politically connected companies have higher financial leverage than non-politically connected companies. Linked to this, Gul (2006) also indicated that politically connected Malaysian companies were subjected to higher (lower) audit quality during periods of financial crisis (stability). Bliss and Gul (2012) also investigated the association between interest rates and politically connected status. It was discovered that in Malaysia, the private debt market regards politically connected companies as having higher operating risks. The findings also suggest that the market regards independent audit committees and independent boards of directors as factors that mitigate this risk. Mitchell and Joseph (2010) documented evidence which showed that one type of politically connected companies such as the investees of Khazanah Nasional Berhad (the investment arm of the Malaysian Ministry of Finance) had underperformed during periods when capital controls were removed. This finding revealed by Mitchell and Joseph (2010) is consistent with the differences noted in the temporal variations of corporate performance between the investees of Khazanah Nasional Berhad and the GLCs (two different types of politically connected companies). Based on the 2008 Federal election disappointment of Barisan Nasional, the ruling coalition, Fung et al. (2015) investigated the association between politically connected status and long-term financial health. Their results suggest that political connections added more shareholder value when they are longstanding and when the politically connected company employed professional managers and directors. In comparison, the findings of Sinnadurai (2016) imply that Malaysian companies with a shareholder connection related to economic policy (but not Malaysian companies with other types of political connections) enjoyed higher abnormal earnings growth rates (Ohlson, 2005). Tee et al. (2017) examined the association between shareholdings by institutional investors and audit quality (measured by 
the amount of audit fees) and it was found that the positive association between institutional ownership and audit fees was stronger for politically connected companies. This finding similarly supports the view that politically connected companies have higher agency costs of equity, thereby creating a need for higher quality audits as an agency mechanism.

\subsubsection{Suggestions as to How Malaysian Researchers could Build on the Extant Literature on Political Connections}

\section{Adoption of a Formal Definition of "Political Connection" and a Different Classification Regime}

Future Malaysian research looking at political connections could build on the extant evidence by adopting a formal definition of "political connection" and régime for classifying the types of political connections. One suggestion is that a company is politically connected if it receives support from a government because the company's output is amenable to achieving public policy objectives (Demsetz \& Lehn, 1985; Sinnadurai, 2016). Malaysian researchers could distinguish three overlapping categories: companies with a shareholder political connection related to economic policy, companies with a shareholder political connection related to social policy and companies with an informal political connection. The first two categories would have the Malaysian government (state or federal) acting as a shareholder (Fraser et al., 2006).

The first category comprises companies producing outputs that are compatible with the government's economic policy (policy directed at increasing the size of national output) (Fraser et al., 2006; Mitchell \& Joseph, 2010). Examples of investors within this category include the Federal Ministry of Finance, Khazanah Nasional Berhad (the investment arm of the Malaysian Ministry of Finance), Petroliam Nasional Berhad, and the State Economic Development Corporations. During the era of the NEP, the State Economic Development Corporations were formed to serve as the Malaysian state government's investment instruments. They owned shares in selected Malaysian companies which facilitated economic development (Gomez, 2009; Gomez et al., 2018). The second type of politically connected company has outputs amenable to achieving social policy objectives which are related to the redistribution of national wealth (Fraser et al., 2006). Investors in the second category include non-Khazanah GLICs, bumiputera investors that are not GLICs and other investors associated with political parties (Sinnadurai, 
2016). The third category consists of companies in which substantial shareholders, members of the executive or directors have a link (via personal association) to a current or former politician or political party (Faccio, 2006; Gul, 2006; Fraser et al., 2006). These political connections guide the companies to develop business models that are consistent with public policy objectives (Heng \& Sieh, 2004). ${ }^{4}$

A limitation to the proposed classification régime is the blurred boundary existing between economic and social policy. All the GLICs were created as bumiputera trusts during the era of the NEP. Its aim was to increase bumiputera involvement in economic activities and the share of national wealth (Gomez, 2009; Gomez et al., 2018). Consequently, even though some GLICs such as Khazanah Nasional Berhad have a greater focus on economic versus social policies, there were social policy consequences for their activities. At least two strategies could be applied for addressing this limitation. Firstly, as a sensitivity analysis, Malaysian researchers could investigate whether their results are robust in how Khazanah Nasional Berhad is classified. If their results were not sensitive to the classification of Khazanah Nasional Berhad, then the problem of the blurred boundaries between economic and social policy is unlikely to mar their results. Secondly, this limitation may prejudice the research design against producing significant results, enhancing the credibility of any significant results documented (Sinnadurai, 2016).

By using the proposed régime for classifying the types of political connections, future Malaysian research could distinguish between shareholder and non-shareholder political connections. Some evidence of this nature of Malaysian research was documented by Johnson and Mitton (2003) who distinguished companies with shareholder political connections that are related to bumiputera objectives from companies with informal political connections. In another, Faccio (2006) acknowledged that political connections can arise from either large shareholders or corporate executives. Fraser et al. (2006) also documented evidence that companies with both shareholder and non-shareholder political connections have higher leverage than nonpolitically connected companies. Bliss and Gul (2012) alternatively

\footnotetext{
${ }^{4}$ The definition of "political connection" and the classification régime proposed in this paper is similar but not identical to the definitions and classified regimes used by Fraser et al. (2006) and Vithiatharan and Gomez (2014).
} 
used the approaches of Faccio (2006) and Johnson and Mitton (2003) to identify politically connected companies while Boubakri et al. (2012) distinguished whether the political connections originated from a close relation, i.e. a director or a shareholder. The analyses in both Fung et al. (2015) and Tee et al. (2017) included both GLCs and non-shareholder political connections. In this regard, future Malaysian research could build on these studies by investigating more explicitly whether corporate governance characteristics differ between shareholder and non-shareholder political connections. Others could aim to broaden the definition of "shareholder political connections" so as to include shareholders such as the State Economic Development Corporations. ${ }^{5}$

Further, more Malaysian research could be conducted to test the hypotheses by comparing corporate characteristics between companies with different types of shareholder political connections. These hypotheses development could refer to differences in fund management approaches among the different types of shareholder political connections. Most of the political connections related to social policy are active portfolio managers, seeking to maximise portfolio returns for distribution to their beneficiaries (Gomez \& de Micheaux, 2017). Conversely, political connections related to economic policies are more likely to adopt a "buy and hold" approach, seeking active input into the governance of the companies so as to achieve their public policy objectives (Sinnadurai, 2016). The portfolio management strategy adopted by the political connections may affect governance attributes of the investee company.

Some past studies (Fraser et al., 2006; Mitchell \& Joseph, 2010) have investigated whether corporate governance characteristics differ according to the type of shareholder political connection possessed by a company. The empirical tests in Fraser et al. (2006) distinguished companies with political connections related to economic policy from companies with a shareholder political connection that patronises on the basis of ethnicity. The results suggest that both types of politically connected companies carried more debt than non-politically connected companies. The findings of Mitchell and Joseph (2010) were also found to be consistent with the differences noted in temporal variations in

\footnotetext{
${ }^{5}$ There is also Malaysian evidence suggesting that performance differs between types of informal political connections, according whether the support comes from an incumbent or ousted politician (Johnson \& Mitton, 2003; Mitchell \& Joseph, 2010).
} 
corporate performance between investees of Khazanah Nasional Berhad and GLCs. Thus, future Malaysian research could build on these studies by investigating more explicitly whether corporate governance characteristics differ among the types of shareholder political connections.

\section{Consider the ideological mix underlying relevant Government policies in the micro-setting(s) of choice}

Different mixes of the ideologies of laissez-faire economics and the developmental state have been applied by Malaysian governments, in different areas of public policy. As an illustration, the renationalisation of mega projects after the Asian financial crisis may be regarded as emphasising the developmental state. Conversely, the corporatisation of the GLCs may be regarded as emphasising laissez-faire economics. These micro-settings could be classified according to the relevant mix of the developmental state versus laissez-faire economics underlying the applicable government policy. For example, Johnson and Mitton (2003) compared the share market performance of politically connected companies with other companies during the Asian financial crisis and the post-crisis period, characterised by government-imposed restrictions on capital flows into and out of Malaysia. Similarly, Mitchell and Joseph (2010) compared the performance of GLCs and the investees of Khazanah Nasional Berhad (two different types of politically connected companies) during different sub-periods, after the Asian financial crisis. The extent of the Malaysian government's restrictions on capital flows in and out of Malaysia also differed during these sub-periods. Thus, the government can be regarded as placing more emphasis on the ideology of the developmental state during periods of strict capital controls and more emphasis on laissez-faire economics during periods of lax control. Fung et al. (2015) documented evidence which showed that Malaysian companies with longstanding political connections experienced less dramatic share price decreases in response to negative macroeconomic news, unlike companies with relatively recent political connections. A possible interpretation of this result is that companies with longstanding political connections have accrued more experiences in adapting their business models to changes located within the ideological mix underlying government policies.

Future Malaysian research could therefore build on these studies by formally acknowledging the relative mix of the government's ideologies. The ideological mix (and variants therein) could be acknowledged 
in the hypothesis development, research design and conclusion. For example, the finding which indicates that investees of Khazanah Nasional Berhad underperformed during a period of lax capital controls (Mitchell \& Joseph, 2010) support the conclusion that this type of politically connected company performs better in settings that had the government emphasising more on developmental state ideology, rather than the laissez-faire economics. Subsequent studies could also investigate whether this conclusion can be generalised to other types of politically connected companies and under different settings where the developmental state dominates the laissez-faire economics.

\subsection{Nanyang and Other Family Companies}

\subsubsection{Background to the Nanyang Companies in Malaysia}

The socio-political history of Malaysia has generated an abundance of family companies. One type of family company is the Nanyang company. "Nanyang" is a Mandarin term meaning "Southern ocean". The word has evolved to mean ethnic Chinese who have settled in Southeast Asia. Nanyang companies originated from Chinese traders who migrated from Southern China to the present-day ASEAN countries to escape poverty in China (Sinnadurai, 2016).

The management style of Nanyang companies was derived from Confucian values and its reliance on guanxi for doing business. Guanxi is a Mandarin term meaning networks, comprising close-knit circles of customers, creditors, labourers, suppliers and other parties. Originally, guanxi networks were limited to members of the same Chinese dialect groups. Individual Nanyang enterprises were small-scale, focused on selling a single product within a small geographical region (Heng \& Sieh, 2004). Decision-making has traditionally been centralised, vested in the hands of the founding patriarch while subordinates tend to have high levels of loyalty towards the patriarch and family. Most of the shareholders of Nanyang companies have directors and executives who are from the founding family. At the same time, links with China were also maintained (Heng \& Sieh, 2004). Nanyang companies have been successful in generating wealth for the Malaysian Chinese community, partly due to the forces of change and partly due to its survival of guanxi and Confucian values underpinning their business models (Sinnadurai, 2016). 
Nanyang companies have been going through various transformations. One force stimulating this change is the ascendancy of China and Taiwan, after the Cultural Revolution and the Asian financial crisis (Liu, 1998). The opening of China and Taiwan has prompted Nanyang companies to access product and capital markets in Greater China while companies from China and Taiwan have also begun operations in ASEAN-region countries, thereby creating an increased product market competition for Nanyang companies (Yeung, 2006).

Another force of change can be attributed to the globalisation of product and capital markets, prompted by the demise of Communism in Eastern Europe during the 1990s and the opening of the People's Republic of China as a market economy (Siddiquee, 2006). Modernday guanxi networks have expanded beyond Southeast Asia and the Sino world (Liu, 1998; Heng \& Sieh, 2004) through vertical integration and diversification. A typical Nanyang company operates outside of Southeast Asia and the Sino world and is a conglomerate with a range of businesses and geographical segments. A typical contemporary Nanyang company is partly financed by foreign debts and listed on at least one foreign stock exchange (Liu, 1998).

The next force driving change in Nanyang corporations is the policies of the Malaysian government that stress on economic and social development. These policies are particularly directed at improving relations between the Malays and the ethnic Chinese (Liu, 1998). Throughout history, Nanyang entrepreneurs have successfully adapted their business models to be friendly to the Malaysian government's policies. During the NEP era, Nanyang businesses foresaw that their previous approach of employing Malay capitalists as "sleeping partners" would no longer satisfy the government's desire to breed a new entrepreneurial class of Malay. The Nanyang corporations, thus began to actively employ Malays into their businesses, using the Malay partners to foster political connections. Therefore, during the NEP period, Nanyang corporations were able to amass shareholder wealth, notwithstanding constraints imposed by policy settings (Heng \& Sieh, 2004; Gomez, 2009). Following this, Nanyang companies were able to avail themselves of the indigenous capital, in addition to the capital of their traditional networks (Yeung, 2006).

In response to these forces of change, contemporary Nanyang companies utilised the expertise of non-family members such as professional managers. During the "Alliance" period of Malaysian history (19571969), Nanyang companies (and the products and services they retailed) 
had grown beyond their introduction and growth phases. Hence, these companies embraced the need to diversify their business models. Heads of Nanyang companies realised that in order to expand into new industries and new geographical regions, they needed expertise not available within the family (Gomez, 2009). Even within the industry and geographic region of origin, Nanyang entrepreneurs understood that they would be foregoing valuable management candidates, if they only considered recruits from within the founder family. Another requirement was then added where even members of the family were required to have tertiary education (often from Western countries) to be eligible for management level positions (Yeung, 2006). Nanyang corporations accepted that a degree of independent monitoring was needed to ensure accountability within diversified companies and to accept the importance of independent directors (Gomez, 2009). In addition, Nanyang companies also acknowledged that professional management may facilitate the adaptation of their business models to changes imposed by government policies over the long term (Fung et al., 2015). ${ }^{6}$

Despite these forces for change, it was clear that the most essentially defining characteristic of Nanyang companies, guanxi, still prevails. Links to, and support from, Greater China, were still strong. National and provincial governments from China and Taiwan were eager to consolidate the Chinese identity within Southeast Asia and so Nanyang companies were encouraged to invest in Greater China (Liu, 1998; Yeung, 2006). Nevertheless, the family still constitutes as the nucleus of contemporary Nanyang corporations (Heng \& Sieh, 2004; Yeung, 2006; Gomez, 2009) where it holds a significant, if not controlling, share ownership (Yeung, 2006).

Another factor that can explain the success of Nanyang companies is the survival of the Chinese language and culture within the country. Observations show that Malaysia is the only country outside Greater China (with the exception of Singapore) that has a publicly-funded system of Chinese-language education. Malaysian Chinese have the option of sending their children to complete their primary education in Mandarin in government-funded National Type Schools. Following this, they may proceed to a higher system of privately-funded Independent Chinese Secondary Schools where education is conducted in Chinese and where successful students can choose to further their education in China or Taiwan. The Chinese language especially Mandarin also

${ }^{6}$ However, Fung et al. (2015) do not isolate Nanyang companies. 
prevails in Malaysia where Mandarin-language prints, television and radio media is prevalent (Lee \& Heng, 2004) making it a very rich setting for the propagation of the Nanyang companies.

\subsubsection{Suggestions for Agency Theory-based Research Agenda for Malaysian Researchers Investigating Family Companies.}

Two different types of agency relationships of equity exist in family companies: the agency relationship between controlling shareholdermanagers and non-controlling shareholders and the agency relationship between shareholders and managers (Claessens \& Yurtoglu, 2013). International evidence (Wang, 2006; Ali, Chen, \& Radhakrishnan, 2007; Chen, Chen, \& Cheng, 2008) indicates that corporate governance outputs such as earnings quality and disclosure policy, differ between family and non-family companies. Evidence from Malaysia (Amran \& Che Ahmad, 2009; Amran, 2011; Abdullah, Evans, Fraser, \& Tsalavoutas, 2015) corroborates this conclusion, illustrating that the direction of associations between corporate value and board of director attributes, differs between family and non-family companies. The findings of Abdullah et al. (2015) suggest that family companies produced lower quality annual report disclosures but this difference in quality is not incorporated into intrinsic values. Conversely, Ismail and Sinnadurai (2012) were unable to document evidence showing the strength of the positive association between intrinsic values and earnings quality which differed between family-dominated and widely-held companies.

These studies (Liu, 1998, Heng \& Sieh, 2004; Yeung, 2006; Gomez, 2009) do not distinguish the types of family companies. Evidence about family companies per se may not be upheld for Nanyang companies, due to differences in business models and agency mechanisms. One Malaysian study that isolated Nanyang family companies is Sinnadurai (2016). He observed that abnormal earnings growth rates were higher for Nanyang than non-Nanyang companies. To this end, further research could investigate whether other corporate governance outputs and valuation attributes differ between types of Malaysian companies: Nanyang companies, non-Nanyang family companies and non-family companies.

International evidence indicates that one variable with explanatory power for how corporate governance outputs differ among types of family companies is the extent to which professional management are employed. Using data from the United States, Chen, Cheng and Dai (2013) found that family companies with a professional CEO had higher 
CEO turnover - performance sensitivity, when compared to other types of family companies. Based on data derived from the United States, Pérez-González (2006) detected, in cases of CEO change, that when the incoming CEO is an unqualified family member, the subsequent performance deteriorates. However, deterioration of subsequent performance is reduced when the incoming CEO has higher quality tertiary education. Taking data from Thailand, the study conducted by Bertrand, Johnson, Samphantharak and Schoar (2008) found that when control of family companies passed to the second generation, the involvement of professional staff from outside the family reduces the cost of the agency relationship between controlling and non-controlling shareholders. Based on these outcomes, Malaysian researchers are well-positioned to contribute to international literature since Malaysia has substantial variations in the degree of professional management employed within family companies (Fung et al., 2015). However, the evidence highlighting that professional managers ameliorate agency costs of equity when management passes to the second generation (Bertrand et al., 2008; Pérez-González, 2006) may not be generalised to Malaysia, in particular the Nanyang companies, owing to their unique corporate governance characteristics (Liu, 1998; Heng \& Sieh, 2004; Yeung, 2006).

Hence, in synthesis, corporate Malaysia can be described as heterogeneous, based on its family companies. These companies could be distinguished based on two different criteria, which adds to the extent of international literature. The first criterion is the family company status comprising: non-family company, non-Nanyang family company and Nanyang company. The second criterion is the extent to which nonfamily professionals are employed in family companies, as members of the executive and on the board of directors. Previous literature (Ali et al., 2007) has indicated that the relative magnitude of the two types of agency equity relationships and the efficacy of different agency mechanisms vary according to family company status and the extent to which non-family members are employed (Ali et al., 2007).

\section{Research into the Recovery of Financially Distressed Companies}

\subsection{Outline of Practice Note 17}

A company is regarded as having "failed" when it ceases to be a going concern. "Financial distress" is an intermediate state, in which a company is experiencing difficulties but is still a going concern. Typical symptoms of financial distress include the inability to pay financial 
obligations as they mature, recurring losses, suspension of dividends and massive layoffs (Beaver, 1966; Platt \& Platt, 2002). "Corporate recovery" may be defined as the processes by which a distressed company averts failure and returns to being a regular going concern. Theory (see Hofer, 1980; Poston, Harmon, \& Gramlich, 1994; Abdullah, Ismail, \& Sinnadurai, 2018) predicts that corporate recovery is more likely to occur if a distressed company is diagnosed in the early stages of distress. The probability of recovery is also likely to differ according to whether the distressed company pursues a turnaround strategy that is operational (short-term) or strategic (long-term) in nature (Hofer, 1980; Poston et al., 1994; Abdullah et al., 2018).

Bursa Malaysia, the Malaysian Stock Exchange has attempted to operationalise the definition of "financial distress" via Practice Note 17, a listing rule that imposes additional disclosure requirements on distressed companies. As the forerunner to Practice Note 17, Practice Note 4 was implemented by the Malaysian Securities Commission as part of the Mahathir government's reforms, after the Asian financial crisis (Che Haat, Mahenthiran, Abdul Rahman, \& Abdul Hamid, 2006).

Practice Note 17 designates a company as financially distressed if at least one of the following criteria is satisfied:

1. The company's shareholders' funds attributable to parent shareholders are less than 25 per cent of its total paid-up capital and less than RM40 million.

2. Receivers have been appointed to take control of the company's assets, or the assets of a subsidiary or associated company comprising at least 50 per cent of total consolidated assets.

3. Winding-up of a subsidiary and/or associated company that comprises at least 50 per cent of total consolidated assets.

4. The auditor has expressed an adverse opinion or a disclaimer in the most recent set of audited financial statements.

5. Auditors have expressed emphasis of matter regarding the going concern assumption in the most recent financial statement and consolidated shareholders' funds of the issuer are at most, 50 per cent of the consolidated paid-up-capital.

6. Default on debt payments by the issuer, its major subsidiary or its major associated company and the issuer is unable to provide a solvency declaration to Bursa Malaysia.

Poston et al. (1994) identified three stages of financial distress. The first stage, "incubation", refers to the beginning of the financial difficul- 
ties. The second stage is "financial embarrassment" where a company still has positive net assets and sound earnings power but is starting to experience liquidity problems. The third stage is financial insolvency where the liquidity problem has deteriorated to the extent that the company can no longer obtain funds for recovery, whether from internal or external sources. If problems persist at the third stage, the company progresses from financial distress to insolvency. The Practice Note 17 criteria seems to be aimed at identifying companies at the latter stages of financial distress (Casey, McGee, \& Stickney, 1986; Poston et al., 1994).

A company caught by Practice Note 17 (the "issuer") and its principal advisor is required to review the issuer's risk management and the internal control systems. The company is required to submit to Bursa Malaysia the results of the review and the plan to redress the weaknesses reported therein. Bursa Malaysia then assesses the plan according to whether, in the near future, the plan is likely to satisfy the following objectives: redress the problems that caused the issuer to trigger Practice Note 17, prevent the issuer from retriggering Practice Note 17 and increase the value of securities (Bursa Malaysia, 2015).

Companies coming under Practice Note 17 are also required to furnish additional disclosures. Immediately upon being caught by Practice Note 17, the company must issue its "first announcement", disclosing the fact that it is caught by Practice Note 17, its obligations under Practice Note 17 and the consequences of non-compliance. Within three months of the first announcement, the Practice Note 17 issuer is required to furnish a statement indicating whether its regularisation plan will entail substantial changes to its business model. The affected issuer is also required to make monthly announcements, communicating expected timeframes until approval of the regularisation plan. The plan for implementation made by the companies caught under Practice Note 17 is obliged to continue making monthly announcements until informed otherwise by Bursa Malaysia. Companies coming under Practice Note 17 are also required to make a "requisite announcement", containing the aforementioned details of the regularisation plan, after necessary third-party agreements such as compromises by creditors have been concluded (Bursa Malaysia, 2015).

Regularisation requirements differ based on whether the plan entails significant changes to the issuer's business model. If the plan involves substantial changes, the issuer is required to submit the plan to the Malaysian Securities Commission for approval, within 12 months of attaining the Practice Note 17 status. The issuer is then required 
to formalise the plan within a timeframe specified by the Malaysian Securities Commission (Bursa Malaysia, 2015).

If the regularisation plan does not involve substantial changes to the issuer's business model, the issuer is required to meet additional obligations. The plan must clarify which of the Practice Note 17 criteria triggered the application of the practice note. The regularisation plan should contain historical figures of revenue, gross profit, shareholders' funds, borrowings and key financial ratios for whichever is later: five years ago or the listing date. There is a requirement for the discussion and analysis of these historical figures to include, in light of the company's operating environment, key risk factors and industry outlook. If the plan entails the injection of new assets, the issuer is required to disclose names, qualifications and experiences of directors, officers and investors involved in the restructuring. The issuer's board of directors is also required to assess whether the issuer is likely to have sufficient working capital to continue as a going concern for the next twelve months, and whether the issuer is likely to achieve positive earnings during the next two quarters. The plan must contain forecasts of earnings and cash flows, in addition to the explanation of the assumptions underlying the forecasts and the review of the issuer's risk management policies and internal control systems. The issuer not intending to alter the business model is required to implement the plan within 12 months of approval. The issuer is obliged to achieve positive net profits in two consecutive quarters, after implementing the plan (Bursa Malaysia, 2015).

A possible rationale for Practice Note 17 to contain such strict requirements for affected companies not intending to alter their business models is the need to convince Bursa Malaysia and the investors of the plan's viability, notwithstanding the issuer continuing in an industry which is struggling. The Practice Note 17 requirements for companies planning to continue with their existing business models are in agreement with prescriptions in the literature aimed at achieving operating and/or strategic turnarounds by single business units (Hofer, 1980).

\subsection{Literature on the Prediction of Recovery from Corporate Financial Distress}

Studies (Altman, 1968; Ohlson, 1980; Hillegeist, Keating, Cram, \& Lundstedt, 2004) have modelled the probability of corporate recovery from financial distress, using financial statement ratios and metrics. 
In particular, the Altman (1968) and Ohlson (1980) indices, referred to as "Z-scores" and "O-scores" respectively, model the probability of recovery as a function of liquidity, financial leverage, company age, operating profitability, size and asset usage efficiency. The probability of corporate failure has also been estimated using option pricing models. This approach estimates the probability of bankruptcy as the probability that the market value of a company's assets is lower than the book value of its liabilities, within a specified time period (Hillegeist et al., 2004).

Evidence (see Altman, 1968; Ohlson, 1980; Poston et al., 1994; Begley, Ming, \& Watts, 1996; Hillegeist et al., 2004; Wu, Gaunt, \& Gray, 2010) indicates that the predictive accuracy of the aforementioned approaches could improve. The Altman (1968) and Ohlson (1980) metrics have high classification accuracy, when applied to the data from the periods they were developed. However, these metrics have reduced accuracy when applied to different time periods, even when the coefficients are re-estimated. The set of ratios that best predict corporate failure and their coefficients display temporal variation (Poston et al., 1994; Begley et al., 1996; Hillegeist et al., 2004; Wu et al., 2010).

Estimates of the probability of bankruptcy using option pricing models tend to outperform estimates using financial statement ratios. Within-sample and out-of-sample accuracy improves when additional ratios are included as predictors. These additional variables include earnings power, the extent to which assets are collateralised, lagged return, stock price variability and the number of business segments (Casey et al., 1986; Wu et al., 2010). Malaysian researchers, using Practice Note 17 data, have the potential to contribute to filling this void by using the reason(s) for triggering Practice Note 17, as extra predictors for the probability of recovery. Details of the regularisation plan permit assessment of the quality of the corporate governance mechanisms therein and the type of turnaround strategy (operational versus strategic) (Poston et al., 1994).

Studies using financial statement indices and option pricing models to predict corporate bankruptcy experience theoretical and practical challenges which may partially explain the shortcomings of their performances. The Practice Note 17 data have the potential to reduce these shortcomings, for instance, the theoretical challenge to operationalise "financial distress" and "corporate failure" (Karels $\&$ Prakash, 1987). Moreover, the correspondence between the value of a ratio and a company's stage and severity of financial distress is unobservable to researchers and so may vary, cross-sectionally and 
temporally. This means that researchers may misclassify healthy companies as distressed. A company's Practice Note 17 status (as healthy, distressed or failed) reflects the judgment of a professional regulator. This judgment is likely to be more accurate than the result derived solely on financial statement ratios and indices that disregards their inherent limitations.

Another challenge is the incorporation of the impact of corporate governance quality on the probability of corporate failure. Effective monitoring may improve the likelihood of recovery but the relation between the probability of survival and the financial accounting metrics may differ according to corporate governance variables. Evidence (Fich \& Slezak, 2008) indicates that variables measuring corporate governance quality enhance the predictive ability of financial ratios for corporate recovery. In this regard, triggering Practice Note 17 would implicitly incorporate the impact of corporate governance quality where companies with higher corporate governance quality would have higher shareholder values, hence less likely to trigger Practice Note 17.

The prediction of corporate failure using financial ratios may be disadvantaged by statistical problems. This is because multiple discriminant analysis assumes that ratios are distributed normally (or lognormally), both univariately and multivariately. Evidence (Karels \& Prakash, 1987) indicates that these assumptions are only likely to be satisfied for a small sub-set of ratios and that predictive accuracy is much higher when they are satisfied. Using Practice Note 17 to predict corporate failure would thus help to reduce this problem and the reasons for using Practice Note 17 can be captured via a series of indicators, rather than continuous variables.

Using financial statement ratios to predict corporate failure can suffer from sample selection problems. Models that predict corporate failure by using financial ratios tend to over-represent failed companies in their samples (Zmijewski, 1984). This limitation would cause the probability of failure to be over-estimated. Malaysian researchers are able to predict the probability of failure for distressed companies by using Practice Note 17. Since the population of Practice Note 17 companies is regularly published by Bursa Malaysia, the prediction of corporate failure, conditional on being distressed, may be more accurate than through the prediction of failure from a sample of healthy companies.

Previous Malaysian studies such as Abdullah, Halim, Ahmad and Rus (2008) have investigated the probability of financial recovery. They compared the classification accuracy of the multiple discriminant 
analysis model, logistic regressions and the hazard model by using the traditional categories of financial statement ratios (Altman, 1968; Ohlson, 1980). Results indicate that financial leverage is the most consistent predictor of financial distress. In another study, Yap, Yong and Poon (2010) used multiple discriminant analysis to develop a corporate failure prediction model with high out-of-sample classification accuracy. Alifiah, Salamudin and Ahmad (2013) estimated Altman's (1968) style models by using logistic regressions. Their results indicate that the models have high classification accuracy, when applied to both contemporaneous and subsequent period hold-out samples. Similarly, Md Zeni and Ameer (2010) predicted the probability of turnaround likelihood by using a sample of Practice Note 4/Practice Note 17 companies. They compared the prediction accuracy of three different Altman (1968) style models. Their findings suggest that all the three models have high classification accuracy. Pirzada (2017) also estimated an Altman (1968) style model by using multiple discriminant analysis to examine a sample of Malaysian manufacturing companies. The results indicate that variables capturing profitability, liquidity, financial leverage and efficiency are able to predict financial distress. Therefore, Malaysian research could be built on these findings. So far, none of the aforementioned studies had utilised the contents of Practice Note 17 disclosures such as the reason for being caught and the characteristics of the recovery plan as predictors of the probability of corporate recovery. Thus far, Md Zeni and Ameer (2010) represents the only aforementioned study that had distinguished financial distress and corporate failure.

\subsection{Literature on Earnings Management by Financially Distressed Companies}

Literature (Zang, 2012; Roychowdhury, 2006; Cohen, Dey, \& Lys, 2008) has investigated the trade-off between earnings management via accruals manipulation and real earnings management. A company's choice between these modes would reflect its relative costs and benefits. Real earnings management causes a drain on cash flows and competition positions, hence the costs of real earnings management would be negatively related to product market power and financial health (Zang, 2012). Accruals manipulation may result in the violations of accounting standards and extra scrutiny from regulators and auditors (Roychowdhury, 2006). The cost of accruals management would be positively related to the strictness of regulatory régime, negatively 
related to a company's degree of accounting flexibility but positively related to auditor quality (Cohen et al., 2008).

The costs of real versus accrual-based earnings management may be lower for distressed companies. Distressed companies may prefer the negative cash flow consequences of real earnings management to corporate failure, especially if it is confident that the company can recover. In the years prior to failure, managers of distressed companies may hesitate to engage in upward accruals management. This will cause subsequent accrual reversal which can result in an even bleaker picture of their financial positions (García-Lara, García Osma, \& Neophytou, 2009).

These considerations motivate separate investigations of the tradeoff between accruals-based and real earnings management in distressed companies. Evidence (Rosner, 2003; García-Lara et al., 2009) suggests that distressed companies engage in both modes of upward earnings management prior to failure. These studies did not investigate the extent to which distressed companies rely on real versus accruals-based earnings management. Nonetheless, research from Malaysia using Practice Note 17 data has the potential to contribute to the need for this evidence. Companies caught by Practice Note 17 would display a more accurately identified sample of distressed companies which serves research purposes well. In addition, the limitation of relying solely on financial accounting criteria is that earnings may have been managed to circumvent classification as financially distressed and to secure favourable terms from creditors (Rosner, 2003; Mohd Saleh \& Ahmad, 2005). Likewise, this also serves as a good reason for making reference to Practice Note 17 for research aims.

Malaysian studies (Selahudin, Zakaria, \& Mohd Sanusi, 2014; Ghazali, Shafie, \& Mohd Sanusi, 2015) have investigated earnings management by distressed companies. In their work, Selahudin, et al. (2014) were unable to document reliable evidence of the association between accruals management and financial distress. In contrast, Ghazali et al. (2015) managed to document evidence which showed that financially distressed companies engaged in income-decreasing accruals management. Nevertheless, these studies did not utilise Practice Note 17 disclosures neither did they control the level of real earnings management. In another study, Shayan Nia et al. (2017) observed that real earnings management, prior to being caught by Practice Note 17, was constrained by foreign shareholders which may also carry some implications for research. Therefore, subsequent Malaysian researchers 
could build on this evidence by modelling the relative costs and benefits of the two modes of earnings management (Zang, 2012).

\section{Suggestions for Agency Theory-based Researchers from Indonesia, the Philippines and Thailand}

There are many institutional similarities between Malaysia and other ASEAN countries. Hence, some of the recommendations proposed in this paper may be applicable to the neighbouring countries. This section discusses the potential applicability of the suggestions for research into family companies and political connections for Indonesia, the Philippines and Thailand. Consideration of differences and similarities between each of these three countries and Malaysia may spur researchers from these countries to engage in agency theory-based research.

The remainder of this section is organised as follows: the second sub-section discusses political connections. It begins with a general discussion, followed by specific discussions related to Indonesia and the Philippines respectively. The third sub-section dwells on family companies; it also provides an integrated discussion for all the three countries and the fourth sub-section is specifically devoted to Thailand. It focusses on the unique institutional investor of The Crown Property Bureau of Thailand.

\subsection{Political Connections}

\subsubsection{General Discussion}

The global definition of "political connections" as postulated in this review paper applies to Indonesia, the Philippines and Thailand (Demsetz \& Lehn, 1985; Sinnadurai, 2016). All these three countries have companies that receive government assistance because the companies' output is amenable to achieving public policy objectives. In this regard, it is also appropriate for capital market researchers from Indonesia, the Philippines and Thailand to distinguish shareholder political connections from adviser connections. Both categories of political connections abound in all three countries (Carino, 2008; Wurfel, 1999; Pananond, 2001; Carney \& Hamilton-Hart, 2015).

In developing the research hypotheses, it would be appropriate for researchers from Indonesia, the Philippines and Thailand to follow a similar approach to Malaysia. Researchers from these three countries 
should also identify the ideologies underlying their respective government's policies for economic and social development. The researchers should consider how these ideologies differ in the different microsettings and where possible, develop research hypotheses linking politically connected status to corporate characteristics and policies. However, there are marked differences between the ideologies adopted by Malaysian authorities and the ideologies underpinning economic and social development policies in Indonesia, the Philippines and Thailand. Hence, researchers from these three countries would need to mount different arguments, different from those of researchers in Malaysia. Furthermore, researchers from these three countries also need to bear such similarities and differences in mind, when constructing their research designs.

\subsubsection{Indonesia}

The ideologies underpinning post-Suharto Governments' policies for the social and economic development of Indonesia share some similarities with Malaysia. In particular, Indonesian federal governments like their Malaysian counterparts, have embraced a mix of the developmental state and laissez-faire economics (Gomez, 2009; Warburton, 2016). In Indonesia, as in Malaysia, the relative mix of these ideologies has differed both over time and in different micro-settings. For example, since 2014, the Jokowi administration (October, 2014 to the time of writing) has greatly empowered state-owned enterprises by providing special sources of funding, offering them lucrative infrastructure building projects and facilitating intra-industry mergers to consolidate the product market power. The Jokowi administration has also implemented deregulation packages aimed at encouraging private sector investment and it also lifted restrictions on foreign investments in some industries (Warburton, 2016). The Jokowi Government provided substantially more funding for public infrastructure building projects than the Yudhoyono administration did (October, 2004 to October, 2014). The Jokowi administration was also more concerned with attracting private sector investments to participate in these projects (Warburton, 2016). In this regard, Indonesian capital market researchers could develop testable hypotheses, related to the impact of these government policies on corporate governance. For example, product market competition amongst private sector participants may have been fiercer in the Yudhoyono era. Therefore, the potency of product market competition, 
as a determinant of earnings quality and disclosure policy, may have been stronger during the Yudhoyono era (Ali et al., 2014).

There are differences between the ideological underpinnings of the Indonesian and Malaysian governments' policies for social and economic development. In particular, post-Suharto Indonesia may be regarded as a "weakly ethnicised polity", an environment in which resource allocation by the federal government has limited regards for ethnicity. One factor causing this situation is that fiscal and administrative decision-making was decentralised to the provinces. Some of these provinces were heterogeneous, containing many different ethnicities, with different demands. This is a result of the Indonesian government's programmes of resettling Javanese and Madurese to elsewhere in the archipelago. Alternatively, some predominantly mono-ethnic regions have been divided into several provinces, for example, the Javanese heartland is spread over the provinces of Central and East Java. As a result of this, inter-ethnic patronage and communication has become a critical success factor for federal politicians in Indonesia (Aspinall, 2011). Hence, the social policy goal of eliminating the association between ethnicity and economic function is less important in Indonesia than in Malaysia (Siddiquee, 2002; Aspinall, 2011). It seems unlikely that in Indonesia, policies of companies subjected to government shareholding would be influenced by the requirement to provide a steady income stream to indigenous beneficiaries. Instead, the influence of government shareholdings on corporate policy may depend on the nature and degree of reciprocal patronage between politicians and the listed company. A conjecture of this nature could be tested empirically by capital market researchers.

The post-Habibie government of Indonesia had strongly pursued an agenda of reducing the degree of corporate cronyism, secrecy and corruption that prevailed during the Suharto era (October, 1999 to June, 2001) (Leuz \& Oberholzer-Gee, 2006; Warburton, 2016). This change in the Indonesian government's ideology may have reduced the strength of political connections as a determinant of corporate performance. This conjecture can be tested by capital market researchers. Some evidence of this nature exists, as seen in the results of Leuz and Oberholzer-Gee (2006). They suggested that during President Suharto's term, companies close to the President were less likely to utilise foreign sources of public finance due to the domestic support provided by the government. It was further documented that companies close to Suharto suffered a decline in performance during the term of President Abdurrahman Wahid. 
Indonesian researchers are thus advised to use a different measure of political connections than that of Leuz and Oberholzer-Gee (2006), to acquire reliability. The definition of "political connection" in the current paper is broader and focuses on support from the government to achieve public policy objectives, rather than closeness to a particular politician.

Based on the above, it would be appropriate for Indonesian capital market researchers to have different categories of politically connected companies that is unlike their Malaysian counterparts. In Indonesia, it is more common for listed companies to be ultimately owned by the government of a foreign country (Carney \& Hamilton-Hart, 2015). These companies may be treated as a distinct category of shareholder political connections. The shareholders may import governance practices from their countries of origins and this practice affects corporate governance outputs differently from companies dominated by the Indonesian government (Shayan Nia et al., 2017). Indonesian capital market researchers may therefore treat this as a distinct category of political connections where companies are associated with politicobusiness elites who fund politicians and political parties. Due to the Indonesian politicians' reliance on these sources of funding (Aspinall, 2011; Warburton, 2016), it is inevitable that these companies would experience different types of wealth transfers between the politicians and other stakeholders in the companies. In addition, the performance of these companies may be more susceptible to the vagaries of the health and power of the politicians with whom they are connected to (Leuz \& Oberholzer-Gee, 2006). Indonesian capital market researchers could model political contributions from these companies as negative subsidies from Indonesian politicians when conducting research examining financial support towards politically connected companies and also study its impact on corporate performance (Boycko, Shleifer, \& Vishny, 1996).

\subsubsection{The Philippines}

Shareholder political connections in the Philippines, as in Malaysia, have arisen due to the government's policies related to economic development. The New Public Management and privatisations have been embraced as mechanisms to enhance public sector efficiency in the Philippines (Sta Ana, 1998; Carino, 2008). Consequentially, the Philippines, like Malaysia, has some listed companies which are subjected to substantial government ownership. Similar to companies 
with political shareholder connections in Malaysia, government owned and controlled corporations in the Philippines are required to balance the goals of maximising shareholder wealth and achieving public policy objectives. Similarly, there are many government related shareholders in the Philippines, a phenomenon which is heterogeneous, in respect to their missions (Senate Economic Planning Office of the Philippines, 2006). A difference between Malaysia and the Philippines is that Malaysia has not experienced fiscal mismanagement to the magnitude of the Marcos era (Rivera, 1994). The use of privatisations to redress impacts of politicisation in government owned and controlled corporations and to reduce public sector debt has been more imperative in the Philippines than in Malaysia (Sta Ana, 1998; Wurfel, 1999). Therefore, with data from the Philippines, more powerful tests of conjectures from the perspective of economic theory about shareholder wealth impacts of different régimes of government involvement in the private sectors, can be permitted (Boycko et al., 1996).

One suggestion for Filipino researchers is to classify privatised entities that are subjected to substantial government ownership, according to the categories of privatisation (see Sta Ana, 1998). The author distinguished the following categories of privatisations: privatisations primarily undertaken to increase public sector revenue, privatisations undertaken to increase private sector involvement in infrastructure building projects and privatisations of providers of social services. The difference between the ideologies underpinning privatisations in the Philippines versus Malaysia is that regarding social services privatisations where the government of the Philippines sought to "steer, rather than row" (Sta Ana, 1998). This ideology postulates that privatised entities should ultimately determine their own directions with the government acting as a mere enabler and regulator. By contrast, Khazanah Nasional Berhad of Malaysia retains substantial share ownership in its private sector investee companies and also has active input in their corporate governance (Claessens, Djankov \& Lang, 2000). A suggestion for Filipino capital market researchers is to categorise the privatised entities according to the extent to which the government "steered" rather than "rowed", in different settings. The extent to which regulatory intervention influences corporate governance may be greater in settings where the "rowing" dominated the "steering". For example, the relative cost of engaging in accruals management, rather than real earnings management, is likely to be larger in settings characterised by a high degree of regulatory scrutiny (Zang, 2012). 
The nature of government share ownership in the Philippines differs from Malaysia. While the Federal Government of Malaysia's share ownership is principally exercised via one government-related investor, Khazanah Nasional Berhad that owns shares in companies across several industry sectors, ${ }^{7}$ the State Government's share ownership tends to be exercised by the State Economic Development Corporations, bodies that are responsible for cross-sectoral economic development within the state of jurisdiction. Conversely, government share ownerships in Filipino listed companies tend to be exercised by the Federal Government Department, corresponding to the operations of the corporation such as the Department of Energy (Senate Economic Planning Office of the Philippines, 2006). The extent to which corporate output is amendable to achieving public policy objectives is likely to vary among industries (Demsetz \& Lehn, 1985). For example, the activities of the provider of childcare facilities may be more amenable to achieving public health objectives than a manufacturer of tobacco products. Hence, the potential for conflicts between shareholder wealth maximisation and public objectives may be greater in some industries than in others (Senate Economic Planning Office of the Philippines, 2006). The importance of the earnings, as a valuation input and accountability metric, may accordingly, exhibit inter-industry variation (Ismail \& Sinnadurai, 2012). Conjectures of this nature could be investigated by Filipino capital market researchers.

\subsection{Family Companies}

It would be appropriate for capital market researchers from Indonesia, the Philippines and Thailand to distinguish the Nanyang family companies from the non-Nanyang family companies. Both types of family companies abound in all three countries (Semkow, 1995; Batalla, 2010; Tabalujan, 2002; Ouyyanont, 2008; Carney \& Hamilton-Hart, 2015). Further, the Nanyang family companies in Indonesia, the Philippines and Thailand also share many characteristics with their Malaysian counterparts.

\footnotetext{
${ }^{7}$ An exception to this observation is Petroliam Nasional Berhad (PETRONAS), a Federal Government-related institutional investor in Malaysia. PETRONAS' shareholdings reflect more industry concentration, in companies engaged in activities related to oil and gas extraction (Petroliam Nasional Berhad, 2017).
} 
Nanyang companies in Indonesia, the Philippines and Thailand, similar to their Malaysian counterparts, have been successful in generating shareholder wealth. Carney and Hamilton-Hart (2015) documented that six of the ten largest listed Indonesian companies (by total assets) in 1996 were still in the largest ten circle in 2008. Most of the others were within the top 100 in 2008 with the Nanyang companies wellrepresented (Tabalujan, 2002). In 2005, the 22 most dominant private sector companies in the Philippines represented 11 families, mostly of ethnic Chinese background (Batalla, 2010). During the period of 19501980, Nanyang banks in Thailand had achieved higher growth rates than the Siam Commercial Bank, notwithstanding the fact that the latter had also enjoyed special privileges as a shareholding of the country's Crown Property Bureau (Ouyyanont, 2008). A critical success factor for the Nanyang companies in all the four countries is their reliance on family and other networks (Semkow, 1995). Therefore, listed Nanyang companies in Indonesia, Thailand and the Philippines, like Malaysia, are typically large, diversified conglomerates which have used vertical integration, horizontal integration and diversification as their growth strategies. Examples include the Salim group in Indonesia (Sato, 1993; Carney \& Hamilton-Hart, 2015), the companies within Lucio Tan's empire in the Philippines (Batalla, 2010) and companies under the Charoen Pokphand Group in Thailand (Pananond, 2001).

A factor that can explain the success of Nanyang companies in all the four countries is their ability to adapt their business models to be friendly towards national policies for development despite hostile policies directed towards ethnic Chinese. Without doubt, Nanyang companies in Indonesia, the Philippines and Thailand, like those in Malaysia, have been vulnerable to these sentiments (Semkow, 1995). For example, in the era prior to the mid-1980s, the Salim group in Indonesia employed a mixture of ethnic Nanyang and pribumi (indigenous Indonesian) managers. The former oversaw the business in its entirety while the latter ran daily operations and liaised with the Suharto Government (Sato, 1993). In the Philippines, during the period between independence and the reign of President Marcos (1946-1971), legislation prohibiting ethnic Chinese from engaging in retail trade was enacted (Batalla, 2010). Nanyang businesses responded by diversifying into manufacturing industries, including the production of cigarettes, textiles and footwear, coconut and flour products and banking (Rivera, 1994). In Thailand, during the period of 1930-1950, Nanyang business 
enterprises were regarded as pariahs by the indigenous population (Wurfel, 1999). During this period, Nanyang families founded several banks, with the purpose of providing funds for Nanyang businesses (Charumilind et al., 2006).

Like their Malaysian counterparts, the success of Nanyang companies in Indonesia, the Philippines and Thailand can be attributed to the management's ability to adapt their business models, in response to changes in the macroeconomic climate and their country's policies for economic and social development. For example, in Indonesia, during the period of 1968-1974, the Salim group diversified its operations into manufacturing, to take advantage of the Suharto policy that required final processing of consumer goods to be localised. The Salim group expanded into the cement industry during the period of 1977-1981, foreseeing the heightened demands for building products during a period of economic recovery (Sato, 1993). In the Philippines, during the Marcos era, Nanyang entrepreneurs consolidated their wealth by forging political connections with Marcos (Rivera, 1994; Semkow, 1995; Batalla, 2010). The Charoen Pokphand Group is a diversified Nanyang conglomerate from Thailand. In 1993, the group took advantage of privatisation in Thailand and entered into a joint venture arrangement with the state-owned Petroleum Authority of Thailand. The joint venture managed a petrol station network (Pananond, 2001). After progressing to the second generation and beyond, Nanyang companies in Indonesia, the Philippines and Thailand began employing professional managers (in addition to members of the family) on the executive, to facilitate vertical integration and diversification (Sato, 1993; Rivera, 1994; Bertrand et al., 2008).

Although their similarities are obvious, a principal difference between the Nanyang communities in Malaysia and those in Indonesia, the Philippines and Thailand is that the Malaysian Nanyang community had clung to its Sino culture to a much greater extent. Malaysia is the only country outside Greater China (other than Singapore) with a publicly-funded system of Chinese-language education (Tan, 2004). Most Malaysian Chinese attend the Chinese-medium primary schools while some also progress to attending Chinese-medium secondary schools. Most Malaysian Chinese speak Mandarin or at least one Chinese dialect as their mother tongue (Tan, 2004), evidence that they have retained their cultural identity as Chinese. Moreover, Malaysia also has a widespread use of Mandarin-language print, television and radio media (Lee \& Heng, 2004). This contributes to the propagation of 
Nanyang companies. In comparison, however, the Nanyang communities in Indonesia, Thailand and the Philippines have not retained their Sino culture to the same extent. In fact, it is rare for them to be able to communicate in Chinese (Liu, 1998).

There are several reasons why the Nanyang community in Malaysia has followed a different evolutionary path from its counterparts in the neighbouring three countries. The Nanyang community in Malaysia is bigger than those in the other three countries (Lee \& Heng, 2004). Furthermore, the political interests of the Nanyang community in Malaysia have always been well-represented where historically, the Malaysian Chinese Association (MCA) works with the United Malays National Organisation (UMNO) coalition together with other minor parties. Therefore, the interests of the Nanyang corporations are manifested and represented by the leaders of the MCA in terms of policymaking, both at the federal and state levels. In the history of Malaysia, the MCA has influence and the power to soften the prevalence of ketuanan Melayu (Malay supremacy) policies, particularly during periods when the dominant UMNO was plagued by intra-party dissent (Gomez, 2009). This helped to fortify the position of the Nanyang businesses (Lee \& Heng, 2004). Conversely, the Malaysian Chinese community is also represented by the Malaysian political oppositions. Their common objective of advancing the interests of the Malaysian Chinese community is thus stronger (Heng \& Sieh, 2004; Gomez, 2009).

A corollary of these differences of the Nanyang companies in Indonesia, the Philippines and Thailand suggests that other critical success factors may also be in place. There are non-Nanyang family companies in these three countries that have also been as successful as the Nanyang companies. Therefore, the agency theory-based researchers from these three countries will need to be cognisant of the institutional differences so that effective hypotheses and relevant research designs can be constructed. As an illustration, for Indonesian family companies (Nanyang and otherwise), the patronage of politicians and cooperation with government policies may be more important as a critical success factor, than traditional Sino business practices. Hence, it may be appropriate for Indonesian capital market researchers to categorise family companies that are associated with powerful non-Nanyang politico-business elites in the same category as Nanyang companies (Warburton, 2016).

The Philippines also have non-Nanyang family companies that share governance traits as the Nanyang companies. One group of com- 
panies in this category are those owned and managed by descendants of Chinese mestizos ${ }^{8}$ who manage their companies much like the Nanyang companies. They too faced discriminatory treatment and restrictions of business opportunities imposed by the Spanish colonists (Wickberg, 1964). In response to the changes noted in the regulatory régime and economic climate, Chinese mestizo businesses adapted their business models with great effects. For example, during the era of 1850-1898, the Spanish authorities began to fear that they would lose the Philippines to the Unites States, hence, they removed many of the travel and business restrictions previously applied on Chinese mestizos. This was a strategy to enable the Philippines to generate more profits for Spain. The Chinese mestizos, likewise, responded by diversifying into agriculture (a supported industry) and employing more native Filipinos in their businesses (Wickberg, 1964). Even though the Chinese mestizos no longer constitute a distinct cultural grouping within the Philippines, their descendants have maintained their successful business practices. Some of the most profitable companies in the Philippines are family companies managed by ethnic Chinese mestizos, such as companies within the Cojuangco group (Batalla, 2010). Another type of non-Nanyang family company that has enjoyed similar success in the Philippines are companies owned by descendants of the landed capitalists that had arisen to prominence during the post-independence era (Rivera, 1994). A critical success factor of these companies can be attributed to the fact that they provided the support base for presidents and Congress (Wurfel, 1999).

These institutional differences have implications on the Filipino market, hence capital market researchers should consider using a category that is broader than Nanyang companies in their hypothesis development and research design. They could include, within the same grouping as the Nanyang companies, the following types of family companies: family companies that have descended from Chinese mestizo businesses, family companies that originated from non-landed capitalists and family companies that originated from landed capitalists.

\footnotetext{
${ }^{8}$ The Chinese mestizos are descendants of mixed marriages between ethnic Chinese men and native Filipina women, during the era of Spanish colonisation. The Spanish encouraged these mixed marriages, to facilitate Hispanisation of subsequent generations of Chinese traders. The Chinese mestizos were generally afforded preferential treatment, by the Spanish colonists, over the Chinese. Hence, the mestizos developed more cultural affinity with native Filipinos than the Chinese (Wickberg, 1964; Rivera, 1994).
} 


\subsection{The Thai Crown Property Bureau}

A unique entity in Thailand which shares similarities with both the political connections and the Nanyang companies, is the Crown Property Bureau, which is the investment arm of the monarchy. The two principal shareholdings of the Crown Property Bureau are companies listed on the Thai stock exchange: the Siam Commercial Bank and the Siam Cement Group. The Bureau also actively manages a share portfolio via the Crown Property Bureau Equity Company and property investments via The Crown Property Bureau Property Company (Ouyyanont, 2008).

The Crown Property Bureau has many common characteristics with the political connections. For instance, the Bureau is a large institutional investor, whose activities fuel the economic development of the country. Like many of the shareholder political connections related to the economic policy in Malaysia, a significant source of income of the Crown Property Bureau of Thailand is dividends generated by its two principal equity investments. The Crown Property Bureau Equity Company in Thailand, like most of the shareholder political connections of Malaysia, related to social policy actively manages its share portfolio with a view to maximising returns (Ouyyanont, 2008; Gomez, 2009). However, the Crown Property Bureau does not satisfy the definition of a "political connection" as postulated in this review paper. Its function is to generate wealth from investments for the Thai royal family, rather than for the implementation of public policy (Ouyyanont, 2008). A corollary is that Thais doing agency theory-based research should therefore treat the investees of the Crown Property Bureau as a separate category from (any type of) politically connected companies.

The Crown Property Bureau in Thailand shares many common features and critical success factors as the Nanyang companies. It has been extremely successful in generating wealth (Ouyyanont, 2008). It also has a conglomeration of investments. It adopts an aggressive approach to its investment management. Like Nanyang companies, the Bureau has employed diversification and vertical integration as strategies for enhancing its competitive position (Pananond, 2001). Similar to Nanyang companies, the Bureau investees have also been successful in adapting their business models to changes within the economic environment. For example, during the post-Asian financial crisis recovery period, the Siam Cement Group engaged in considerable restructuring, selling non-core businesses. The Bureau reoriented the principal activities of the Siam Cement Group towards the provision 
of cement and construction materials, petrochemicals and paper. These products and services were in demand following the post-crisis situation in Thailand which fueled the demands for building products and services in a resurgent economy (Ouyyanont, 2008). Another critical success factor which the Crown Property Bureau has in common with the Nanyang companies is its ability to utilise networks of finance providers, political connections and technology providers to procure a competitive advantage (Pananond, 2001).

The Crown Property Bureau's association with the royal family of Thailand makes its investees distinct from Nanyang companies. Hence, it would be appropriate for capital market researchers from Thailand to treat Bureau investees (principally the Siam Cement Group and the Siam Commercial Bank) as a separate category from Nanyang companies, in their hypothesis development and also, research designs.

There has been some empirical capital market-based research from Thailand which acknowledges the themes of political connections and family companies. Charumilind et al. (2006) compared Thai companies' access to bank credit and business connections, prior to the Asian financial crisis. The results indicate that during the pre-crisis era, companies with business connections had preferential debt access. Another study by Bertrand et al. (2008) investigated the association between shareholder wealth indicators and the degree of involvement by family members (versus professional managers) in family companies. The results indicate that when leadership passes to the second generation, involvement of professional managers reduces agency costs between family and non-family shareholders. Peetathawatchai and Acaranupong (2012) investigated the association between asset impairment charges and economic indicators mentioned in the relevant accounting standard. The results produced some evidence of opportunistic earnings management in accounting for impairment losses. However, the results also indicate that efficiency dominates opportunism. Acaranupong (2017) used Ohlson's (2005) methodology to investigate the value relevance of book values of investment properties of listed Thai companies. The findings were mixed.

Subsequent Thai studies could build on the extant literature by investigating whether the findings are robust to the suggestions in this review paper. For example, Charumilind et al. (2006) used two different approaches to identify politically-related companies. The first measure treated companies as politically connected if one of the largest family conglomerates in Thailand ultimately owned at least 10 per cent 
of ordinary equity. The other measure is continuous, the percentage of directors of a company who are also on the board of directors of one of the listed family, or on the board of Crown Property Bureau-controlled banks. Their findings may not be robust, based on the alternative definition of political connections that require the connection to be involved in implementing public policy. In this regard, future research could investigate whether the aforementioned findings of Bertrand et al. (2008) were upheld for both the Nanyang and non-Nanyang companies. Within Thailand, the incentives for opportunistic earnings management may differ according to family company status (non-family company, Nanyang company or non-Nanyang family company). Hence, further research could extend the findings of Peetathawatchai and Acaranupong (2012) and Acaranupong (2017) by repeating the analyses for samples stratified according to family company status.

\section{Summary and Conclusions}

This paper presents a vision for conducting agency theory-based research for researchers who come from the ASEAN region, to contribute to the international literature of this discipline. While the main focus of this review paper was on Malaysia, the discussion is also extended to Indonesia, the Philippines and Thailand. The paper suggests an alternative operationalisation of "corporate governance" quality for Malaysian researchers. The subsequent suggestion for Malaysian capital market researchers relate to three streams of literature: research investigating the association between politically connected status and corporate attributes, literature investigating the association between family company status and corporate attributes, and literature on corporate financial recovery. The final section provides the comparison and contrast between Malaysia and the three aforementioned countries of ASEAN, with respect to political connections and family companies. The section makes suggestions which are designed to stimulate the use of the agency theory-based approach by researchers in these countries.

Theoretical definitions of corporate governance quality from the Anglo-American setting refers to the effectiveness of agency mechanisms in reducing residual loss (Jensen \& Meckling, 1976; Bhagat et al., 2008). The Anglo-American approaches to operationalising these definitions tend to utilise the board of directors characteristics (Boone et al., 2007; Bhagat et al., 2008; Coles et al., 2008; Coles et al., 2014) for assessment. Most extant research looking at corporate governance quality in 
Malaysia (Abdul Wahab et al., 2007; Che Haat et al., 2008; Bliss \& Gul, 2012; Goh et al., 2014) had used Anglo-American approaches possibly because as a former colony, Malaysia had inherited many British institutional features (Vithiatharan \& Gomez, 2014).

The theoretical definitions of corporate governance quality adopted from the Anglo-Americans accurately characterises Malaysia. However, using the Anglo-American approaches to operationalise these definitions may be sub-optimal for Malaysia while using the board of directors as an agency mechanism may also be less precise due to the diminished importance of the approach and the board in the Malaysian context. Boards are likely to be "captured" by management, particularly in family companies (Yeung, 2006) thus, a more suitable approach may be to emphasise the characteristics of the management team and also auditor quality. A "strong" management would be selective of shareholder wealth maximising policies, regardless of agency costs (Hu \& Kumar, 2004). High quality audits would enhance the usefulness of financial statements, as a monitoring mechanism, to compensate for controlling shareholders who are able to insulate the management from marketrelated disciplinary threats (Ismail \& Sinnadurai, 2012; Goh et al., 2014). Some Malaysian researches (Fung et al., 2015; Tee et al., 2017) have also used similar measures of corporate governance quality of this nature.

To proceed, some definitions are in place. Here, a new definition of "political connections" and a new régime for classifying political connections are postulated. A company is "politically connected" if it receives some form of government support because its output is amenable to achieving public policy objectives (Demsetz \& Lehn, 1985; Sinnadurai, 2016). This definition is broader than those in previous studies (Fraser et al., 2006; Vithiatharan \& Gomez, 2014). The régime for classification in the current study distinguishes shareholder political connections from informal non-shareholding links. Shareholder political connections are distinguished according to whether the government-related shareholder is focused on economic versus social policy. It would be appropriate for future Malaysian researchers to use a broader definition of "shareholder political connections" than most prior studies (Johnson \& Mitton, 2003; Fraser et al., 2006; Gul, 2006; Mitchell \& Joseph, 2010; Bliss \& Gul, 2012; Fung et al., 2015; Tee et al., 2017) had done so by including investors such as the State Economic Development Corporations.

Future Malaysian research could investigate how the impact of political connections on corporate governance outputs differ according to several criteria. The governance of politically connected companies 
may differ according to the emphasis placed by the Malaysian government on the developmental state versus laissez-faire ideologies, in facilitating economic and social development (Gomez, 2009; Gomez et al., 2018). In their hypothesis development and research design, future Malaysian researchers could also acknowledge more explicitly, the mix of these two ideologies underpinning government policy in the settings they investigate. Future studies could also consider a broader range of corporate characteristics and outputs (Johnson \& Mitton, 2003; Gul, 2006; Mitchell \& Joseph, 2010; Fung et al., 2015). In addition, Malaysian researchers could investigate how corporate characteristics differ according to different types of shareholder political connections. Without doubt, future research could augment extant literature of this nature (Fraser et al., 2006; Mitchell \& Joseph, 2010) by categorising the different types of government-related shareholders according to their policy missions and portfolio management approaches (Sinnadurai, 2016; Gomez \& de Micheaux, 2017).

Malaysian research could contribute to the need for evidence on family companies. These companies experience an agency relationship between family shareholders (who are also managers) and nonfamily shareholders, in addition to the relationship between managers and shareholders. Hence, the nature of agency costs and the efficacy of agency mechanisms may differ between family and non-family companies (Wang, 2006; Ali et al., 2007; Chen et al., 2008; Claessens \& Yurtoglu, 2013). Research from Malaysia has the potential to contribute to this literature because socio-political factors have resulted in a high concentration of family companies in Malaysia (Heng \& Sieh, 2004; Gomez \& de Micheaux, 2017).

The magnitude of agency costs and the efficacy of agency mechanisms may also differ among family companies. International literature (Pérez-González, 2006; Bertrand et al., 2008; Chen et al., 2013) indicates that after the founding generation, agency costs were reduced via the engagement of qualified professional managers, in addition to family members. Malaysian researchers are also privileged to contribute to this literature since Malaysia varies substantially in the degree of professional management employed within family companies (Fung et al., 2015). International evidence may not be generalised to Malaysia, particularly Malaysian Nanyang companies, owing to their unique governance characteristics (Liu, 1998; Heng \& Sieh, 2004; Yeung, 2006; Gomez \& de Micheaux, 2017). Research could therefore build on existing studies (Amran \& Che Ahmad, 2009; Amran, 2011; Ismail \& Sinnadurai, 
2012; Abdullah et al., 2015; Sinnadurai, 2016) by distinguishing Nanyang and non-Nanyang family companies (Gomez \& de Micheaux, 2017).

Malaysian researchers are also blessed with the unique opportunity to contribute to literature on recovery from corporate financial distress. In this context, researchers may utilise data available due to Practice Note 17, a listing requirement imposing extra disclosure requirements on distressed companies (Che Haat et al., 2006). Most existing studies which predict corporate recovery have used financial statement items as predictors, based on seminal models (Altman, 1968; Ohlson, 1980) which also carry many limitations. The set of ratios that best predict corporate failures and their coefficients, vary temporally (Poston et al., 1994; Begley et al., 1996; Hillegeist et al., 2004; Wu et al., 2010). Measurement error is induced due to the difficulty in categorising companies as healthy or distressed. The financial statement ratios are, therefore unlikely to be normally distributed (Karels \& Prakash, 1987) and failed companies are likely to be over-represented in the samples (Zmijewski, 1984).

These problems could be reduced if Malaysian researchers could consider using Practice Note 17 disclosures to identify the distressed companies and also to include these disclosures as predictors for the probability of recovery. These predictors may capture corporate governance factors (hence the effectiveness of agency mechanisms) more accurately than by relying solely on financial statement items (Fich \& Slezak, 2008). This can augment current existing Malaysian studies (Abdullah et al., 2008; Md Zeni \& Ameer, 2010; Yap et al., 2010; Alifiah et al., 2013; Pirzada, 2017).

International literature has investigated the extent to which distressed companies rely on accrual-based management versus real earnings management. Evidence from healthy companies illustrating the trade-off between these modes of earnings management, however, may not be generalised to distressed companies because the relative costs and benefits may differ (Zang, 2012). Future Malaysian research could, henceforth extend on current existing studies (Selahudin et al., 2014; Ghazali et al., 2015; Shayan Nia et al., 2017) by formally modelling the extent to which distressed companies engage in the two modes of earnings management.

Scholars from Malaysia's neighbouring countries doing agency theory-based research, could benefit by comparing and contrasting the Malaysian institutional setting with their own countries. The environments of Indonesia, the Philippines and Thailand are also apposite for contributing to empirical evidence on how political connections and 
family company status affect corporate governance outputs. Researchers in these countries are advised to use the same broad definition of "political connections" postulated in this paper (Demsetz \& Lehn, 1985; Sinnadurai, 2016). It would also be appropriate for them to distinguish the shareholder and non-shareholder political connections. It is further recommended that, similar to the Malaysian researchers, they develop hypotheses via consideration of the ideologies (and mix thereof) that underpin their governments' policies for economic and social development (Gomez, 2009; Gomez et al., 2018). Researchers in these three countries could then distinguish the Nanyang versus the non-Nanyang family companies in their hypotheses and research designs.

\section{References}

Abdul Wahab, E.A., How, J.C.Y., \& Verhoeven, P. (2007). The impact of the Malaysian Code on Corporate Governance: Compliance, institutional investors and stock performance. Journal of Contemporary Accounting and Economics, 3(2), 106-129. http://dx.doi.org/10.1016/S1815-5669(10)70025-4

Abdullah, M., Evans, L., Fraser, I., \& Tsalavoutas, I. (2015). IFRS mandatory disclosures in Malaysia: The influence of family control and the value (ir)relevance of compliance levels. Accounting Forum, 39(4), 328-348. http:// dx.doi.org/10.1016/j.accfor.2015.05.003

Abdullah, N., Ismail, N., \& Sinnadurai, P. (2018). Development of a Malaysiaspecific model for prediction of corporate recovery (Working paper). Shah Alam, Malaysia: Universiti Teknologi MARA \& Sydney, New South Wales: Macquarie University.

Abdullah, N.A.H., Ahmad, A.H., \& Md Rus, R. (2008). Predicting corporate failure of Malaysia's listed companies: Comparing multiple discriminant analysis, logit regression and the hazard model. International Research Journal of Finance and Economics, 15(May), 201-217.

Acaranupong, K. (2017). Accounting practices and value relevance of investment property: Evidence from firms listed on the stock exchange of Thailand. Asian Journal of Business and Accounting, 10(2), 1-41.

Ali, A., Chen, T-Y., \& Radhakrishnan, S. (2007). Corporate disclosures by family firms. Journal of Accounting and Economics, 44(1), 238-286. http://dx.doi. org/10.1016/j.jacceco.2007.01.006

Ali, A., Klasa, S., \& Yeung, E. (2014). Industry concentration and corporate disclosure policy. Journal of Accounting and Economics, 58(2-3), 240-264. http:/ / dx.doi.org/10.1016/j.jacceco.2014.08.004

Alifiah, M.N., Salamudin, N., \& Ahmad, I. (2013). Prediction of financial distress: Companies in the consumer products sector in Malaysia. Jurnal Teknologi (Sciences and Engineering), 64(1), 85-91. http://dx.doi.org/10.11113/jt.v64. 1181 
Altman, E.I. (1968). Financial ratios, discriminant analysis and the prediction of corporate bankruptcy. Journal of Finance, 23(4), 589-609. http://dx.doi.org/ 10.1111/j.1540-6261.1968.tb00843.x

Amran, N.A. (2011). Corporate governance mechanisms and company performance: Evidence from Malaysia. International Review of Business Research Papers, 7(6), 101-114.

Amran, N.A., \& Che Ahmad, A. (2009). Family business, board dynamics and firm value: Evidence from Malaysia. Journal of Financial Reporting and Accounting, 7(1), 53-74. http://dx.doi.org/ 10.1108/19852510980000641

Aspinall, E. (2011). Democratization and ethnic politics in Indonesia: Nine theses. Journal of East Asian Studies, 11(2), 289-319. http://dx.doi.org/ $10.1017 /$ S1598240800007190

Batalla, E.V. (2010). Entrepreneurship and Philippine development. Canadian Journal of Development Studies, 31(3-4), 341-365. http://dx.doi.org/ 10.1080/02255189.2010.3673724

Baxter, P., \& Cotter, J. (2009). Audit committees and earnings quality. Accounting and Finance, 49(2), 267-290. http://dx.doi.org/10.1111/j.1467-629X.2008. 00290.x

Beaver, W. (1966). Financial ratios as predictors of failure. Journal of Accounting Research, 4 (Empirical Research in Accounting: Selected Studies: 1966), 71-111. http:/ / dx.doi.org/10.2307/2490171

Becker, C.L, Defond, M.L., Jiambalvo, J., \& Subramanyam, K.R. (1998). The effect of audit quality on earnings management. Contemporary Accounting Research, 15(1), 1-24. http:/ / dx.doi.org/10.1111/j.1911-3846.1998.tb00547.x

Begley, J., Ming, J., \& Watts, S. (1996). Bankruptcy classification errors in the 1980s: An empirical analysis of Altman's and Ohlson's models. Review of Accounting Studies, 1(4), 267-284.

Bertrand, M., Johnson, S., Samphantharak, K., \& Schoar, A. (2008). Mixing family with business: A study of Thai business groups and the families behind them. Journal of Financial Economics, 88(3), 466-498. http://dx.doi.org/ 10.1016/j.jfineco.2008.04.002

Bhagat, S., Bolton, B., \& Romano, R. (2008). The promise and peril of corporate governance indices. Columbia Law Review, 108(8), 1,803-1,882.

Bliss, M.A., \& Gul, F.A. (2012). Political connection and cost of debt: Some Malaysian evidence. Journal of Banking E Finance, 36(5), 1,520-1,527. http:/ / dx.doi.org/ 10.1016/j.jbankfin.2011.12.011

Boone, A.L., Field, L.C., Karpoff, J.M., \& Raheja, C.G. (2007). The determinants of corporate board size and composition: An empirical analysis. Journal of Financial Economics, 85(1), 66-101. http://dx.doi.org/10.1016/j.jfineco. 2006.05.004

Boubakri, N., Guedhami, O., Mishra, D., \& Saffar, W. (2012). Political connections and the cost of equity capital. Journal of Corporate Finance, 18(3), 541559. http:/ /dx.doi.org/10.1016/j.jcorpfin.2012.02.005 
Boycko, M., Shleifer, A., \& Vishny, R.W. (1996). A theory of privatization. The Economic Journal, 106(435), 309-319. http://dx.doi.org/10.2307/2235248

Bursa Malaysia Securities Berhad. (2015). Practice Note 17: Criteria and Obligations of PN17 Issuers. Retrieved from http://www.bursamalaysia.com

Carino, L.V. (2008). Towards a strong republic: Enhancing the accountability of the Philippine state. Public Administration Quarterly, 32(1), 59-92.

Carney, R.W., \& Hamilton-Hart, N. (2015). What do changes in corporate ownership in Indonesia tell us? Bulletin of Indonesian Economic Studies, 51(1), 123-145. http:/ / dx.doi.org/10.1080/00074918.2015.1016570

Casey, C., McGee, V., \& Stickney, C. (1986). Discriminating between reorganized and liquidated firms in bankruptcy. The Accounting Review, 61(2), 249-262.

Charumilind, C., Kali R., \& Wiwattanakantang, Y. (2006). Connected lending: Thailand before the crisis. The Journal of Business, 79(1), 181-218. http:// dx.doi.org/ 10.1086/497410

Che Haat, M.H., Abdul Rahman, R., \& Mahenthiran, S. (2008). Corporate governance, transparency and performance of Malaysian companies. Managerial Auditing Journal, 23(8), 744-778. http://dx.doi. org/10.1108/02686900810899518

Che Haat, M.H., Mahenthiran, S., Abdul Rahman, R., \& Abdul Hamid, N. (2006). Agency costs as a factor in the suspension of companies from the Kuala Lumpur Stock Exchange. Journal of Contemporary Accounting \& Economics, 2(1), 99-121. http://dx.doi.org/10.1016/S1815-5669(10)70018-7

Chen, S., Chen, X., \& Cheng, Q. (2008). Do family firms provide more or less disclosure? Journal of Accounting Research, 46(3), 499-536. http://dx.doi. org/10.1111/j.1475-679X.2008.00288.x

Chen, X., Cheng, Q., \& Dai, Z. (2013). Family ownership and CEO turnovers. Contemporary Accounting Research, 30(3), 1,166-1,190. http://dx.doi.org/ 10.1111/j.1911-3846.2012.01185.x

Claessens, S., Djankov, S., \& Lang, L.H.P. (2000). The separation of ownership and control in East Asian corporations. Journal of Financial Economics, 58(12), 81-112. http://dx.doi.org/10.1016/S0304-405X(00)00067-2

Claessens, S., \& Fan, J.P.H. (2002). Corporate governance in Asia: A survey. International Review of Finance, 3(2), 71-103. http://dx.doi.org/10.1111/ $1468-2443.00034$

Claessens, S., \& Yurtoglu, B.B. (2013). Corporate governance in emerging markets: A survey. Emerging Markets Review, 15(June), 1-33. http://dx.doi. org/10.1016/j.ememar.2012.03.002

Cohen, D.A., Dey A., \& Lys, T.Z. (2008). Real and accruals-based earnings management in the pre- and post-Sarbanes-Oxley periods. The Accounting Review, 83(3), 757-787. http://dx.doi.org/10.2308/accr.2008.83.3.757

Coles, J.L., Daniel, N.D., \& Naveen, L. (2008). Boards: Does one size fit all? Journal of Financial Economics, 87(2), 329-356. http://dx.doi.org/10.1016/j. jfineco.2006.08.008 
Coles, J.L., Daniel, N.D., \& Naveen, L. (2014). Co-opted boards. Review of Financial Studies, 27(6), 1,751-1,796. http:/ /dx.doi.org/10.1093/rfs/hhu011

Daily, C.M., \& Dalton, D.R. (1997). CEO and board chair roles held jointly or separately: Much ado about nothing? Academy of Management Perspectives, 11(3), 11-20. http:/ / dx.doi.org/10.5465/ame.1997.9709231660

Demsetz, H., \& Lehn, K. (1985). The structure of corporate ownership: Causes and consequences. Journal of Political Economy, 93(6), 1,155-1,177. http:// dx.doi.org/10.1086/261354

Dynaquest Sendirian Berhad. (n.d.). Dynaquest Sendirian Berhad - The Pioneer Independent Investment Advisor. Retrieved from http://www.dynaquest. com.my

Faccio, M. (2006). Politically connected firms. American Economic Review, 96(1), 369-386. http:/ / dx.doi.org/10.1257/000282806776157704

Fich, E., \& Slezak, S. (2008). Can corporate governance save distressed firms from bankruptcy? An empirical analysis. Review of Quantitative Finance and Accounting, 30(2), 225-251.

Fraser, D.R., Zhang, H., \& Derashid, C. (2006). Capital structure and political patronage: the case of Malaysia. Journal of Banking and Finance, 30(4), 12911308. http:/ / dx.doi.org/10.1016/j.jbankfin.2005.05.008

Fung, S., Gul, F., \& Radhakrishnan, S. (2015). Corporate political connections and the 2008 Malaysian election. Accounting, Organizations and Society, 43, 67-86. http:/ / dx.doi.org/10.1016/j.aos.2015.04.001

García-Lara, J.M, García Osma, B., \& Neophytou, E. (2009). Earnings quality in ex-post failed firms. Accounting and Business Research, 39(2), 119-138 http:/ / dx.doi.org/10.1080/00014788.2009.9663353

Ghazali, A.W., Shafie, N.A., \& Mohd Sanusi, Z. (2015). Earnings management: An analysis of opportunistic behaviour, monitoring mechanism and financial distress. Procedia Economics and Finance, 28, 190-201. http:/ /dx.doi. org/10.1016/S2212-5671(15)01100-4

Goh, C.F., Rasli, A., \& Khan, S.U.R. (2014). CEO duality, board independence, corporate governance and firm performance in family firms: Evidence from the manufacturing industry in Malaysia. Asian Business $\mathcal{E}$ Management, 13(4), 335-357. http:/ / dx.doi.org/10.1057/abm.2014.4

Gomez, E.T. (2009). The rise of fall of capital: Corporate Malaysia in historical perspective. Journal of Contemporary Asia, 39(3), 345-381. http:/ / dx.doi.org/ 10.1080/00472330902944404

Gomez, E.T., \& de Micheaux, E.L. (2017). Diversity of Southeast Asian capitalisms: Evolving state-business relations in Malaysia. Journal of Contemporary Asia, 47(5), 792-814. http:/ /dx.doi.org/10.1080/00472336.2017.1322629

Gomez, E.T., Fisal, F., Padmanabhan, T., \& Tajuddin, J. (2018). Governments in business: Diverse forms of intervention (Malaysia GLC Monitor 2018, GLC-_ Report-V10). Kuala Lumpur, Malaysia: Institute for Democracy and Economic Affairs. 
Gompers, P., Ishii, J., \& Metrick, A. (2003). Corporate governance and equity prices. The Quarterly Journal of Economics, 118(1), 107-156. http://dx.doi. org/10.1162/00335530360535162

Gul, F.A. (2006). Auditors' response to political connections and cronyism in Malaysia. Journal of Accounting Research, 44(5), 931-963. http:/ /dx.doi.org/ 10.1111/j.1475-679X.2006.00220.x

Haron, H., Jantan, M., \& Pheng, E.G. (2005). Audit committee compliance with Kuala Lumpur Stock Exchange listing requirements. International Journal of Auditing, 9(3), 187-200. http://dx.doi.org/10.1111/j.1099-1123.2005.00256.x

Hashim, H.A., \& Susela Devi, S. (2008). Board independence, CEO duality and accrual management: Malaysian evidence. Asian Journal of Business and Accounting, 1(1), 27-46.

Heng, P.K., \& Sieh Lee, M.L. (2004). The Chinese business community in Peninsular Malaysia - 1957-1999. In K.H. Lee \& C.B. Tan (Eds.), The Chinese in Malaysia (2nd impression, pp. 123-168), Shah Alam, Malaysia: Oxford University Press.

Hillegeist, S.A., Keating, E.K., Cram, D.P., \& Lundstedt, K.G. (2004). Assessing the probability of bankruptcy. Review of Accounting Studies, 9(1), 5-34.

Hofer, C.W. (1980). Turnaround strategies. Journal of Business Strategy, 1(1), 1931. http:/ /dx.doi.org/10.1108/eb038886

Houston, J.F., Jiang, L., Lin, C., \& Ma, Y. (2014). Political connections and the cost of bank loans. Journal of Accounting Research, 52(1), 193-243. http:// dx.doi.org/10.1111/1475-679X.12038

$\mathrm{Hu}$, A., \& Kumar, P. (2004). Managerial entrenchment and payout policy. Journal of Financial and Quantitative Analysis, 39(4), 759-790. http://dx.doi. org/10.1017/S0022109000003203

Ismail, N., \& Sinnadurai, P. (2012). Does ownership concentration type affect the mapping of earnings quality into value? Malaysian evidence. Journal of Business and Policy Research, 7(3), 24-47.

Jensen, M.C., \& Meckling, W.H. (1976). Theory of the firm: Managerial behavior, agency costs and ownership structure. Journal of Financial Economics, 3(4), 305-360. http:/ / dx.doi.org/10.1016/0304-405X(76)90026-X

Johnson, S., \& Mitton, T. (2003). Cronyism and capital controls: Evidence from Malaysia. Journal of Financial Economics, 67(2), 351-382. http://dx.doi. org/10.1016/S0304-405X(02)00255-6

Karels, G.V., \& Prakash, A.J. (1987). Multivariate normality and forecasting of business bankruptcy. Journal of Business Finance and Accounting, 14(4), 573593. http:/ / dx.doi.org/10.1111/j.1468-5957.1987.tb00113.x

Khazanah Nasional Berhad. (2015). Khazanah Nasional Berhad. Retrieved from http:/ / www.khazanah.com.my

Lee, K.H., \& Heng, P.K. (2004). The Chinese in the Malaysian political system. In K.H. Lee \& C.B. Tan (Eds.), The Chinese in Malaysia (2nd impression, pp. 194-227), Shah Alam, Malaysia: Oxford University Press. 
Leuz, C., \& Oberholzer-Gee, F. (2006). Political relationships, global financing and corporate transparency: Evidence from Indonesia. Journal of Financial Economics, 81(2), 411-439. http://dx.doi.org/10.1016/j.jfineco.2005.06.006

Liu, H. (1998). Old linkages, new networks: The globalisation of overseas Chinese voluntary associations and its implications. China Quarterly, 155 (September), 588-609. http://dx.doi.org/10.1017/S0305741000050001

Malaysian Institute of Corporate Governance. (2016). Malaysian Institute of Corporate Governance. Retrieved from http://www.micg.org.my/

Malaysian Securities Commission. (2017). Malaysian Code of Corporate Governance. Retrieved from https://www.sc.com.my/wp-content/uploads/eng/html/ $\mathrm{cg} / \mathrm{mccg} 2017 . \mathrm{pdf}$

Mangena, M., \& Pike, R. (2005). The effect of audit committee shareholding, financial expertise and size on interim financial disclosures. Accounting and Business Research, 35(4), 327-349. http://dx.doi.org/10.1080/00014788.2005. 9729998

Md Zeni, S., \& Ameer, R. (2010). Turnaround prediction of distressed companies: Evidence from Malaysia. Journal of Financial Reporting and Accounting, 8(2), 143-159. http:/ / dx.doi.org/10.1108/19852511011088398

Mitchell, H., \& Joseph, S. (2010). Changes in Malaysia: Capital controls, Prime Ministers and political connections. Pacific-Basin Finance Journal, 18(5), 460476. http://dx.doi.org/10.1016/j.pacfin.2010.05.002

Mohd Saleh, N., \& Ahmad, K. (2005). Earnings management of distressed firms during debt renegotiations. Accounting and Business Research, 35(1), 69-86. http://dx.doi.org/10.1080/00014788.2005.9729663

Ohlson, J.A. (1980). Financial ratios and the probabilistic prediction of bankruptcy. Journal of Accounting Research, 18(1), 109-131. http://dx.doi.org/ $10.2307 / 2490395$

Ohlson, J.A. (2005). On accounting-based valuation formulae. Review of Accounting Studies, 10(2-3), 323-347. http://dx.doi.org/10.1007/s11142-0051534-4

Ouyyanont, P. (2008). The Crown Property Bureau in Thailand and the crisis of 1997. Journal of Contemporary Asia, 38(1), 166-189. http://dx.doi.org/ 10.1080/00472330701652018

Pananond, P. (2001). The making of Thai multinationals: A comparative study of the growth and internationalization process of Thailand's Charoen Pokphand and Siam Cement Groups. Journal of Asian Business, 17(3), 41-70.

Peetathawatchai, P., \& Acaranupong, K. (2012). Are impairment indicators and losses associated in Thailand? Journal of Financial Reporting and Accounting, 10(1), 95-114. http://dx.doi.org/10.1108/19852511211237462

Pérez-González, F. (2006). Inherited control and firm performance. American Economic Review, 96(5), 1,559-1,588. http://dx.doi.org/10.1257/aer.96.5. 1559

Petroliam Nasional Berhad. (2017), PETRONAS. Retrieved from http://www. petronas.com.my 
Pirzada, K. (2017). Forecast of financial distress: Investigation of Malaysian companies. Accounting and Finance Review, 2(3), 78-92.

Platt, H.D., \& Platt, M.B. (2002). Predicting corporate financial distress: Reflections on choice-based sample bias. Journal of Economics and Finance, 26(2), 184-199. http:/ / dx.doi.org/10.1007/BF02755985

Ponnu, C.H. (2008). Corporate governance structures and the performance of Malaysian public listed companies. International Review of Business Research Papers, 4(2), 217-230.

Poston, K.M., Harmon, W., \& Gramlich, J.D. (1994). A test of financial ratios as predictors of turnaround versus failure among financially distressed firms. Journal of Applied Business Research, 10(1), 41-56. http://dx.doi.org/ 10.19030/jabr.v10i1.5962

Putrajaya Committee on GLC High Performance. (2005). Catalysing GLC transformation to advance Malaysia's development. Retrieved from http://www. pcg.gov.my/

Ramly, Z. (2012). Impact of corporate governance quality on the cost of equity capital in an emerging market: Evidence from Malaysian listed firms. African Journal of Business Management, 6(4), 1,733-1,748. http://dx.doi. org/10.5897/ AJBM10.1624

Richardson, S. (2006). Over-investment of free cash flow. Review of Accounting Studies, 11(2-3), 159-189. http:/ / dx.doi.org/10.1007/s11142-006-9012-1

Rivera, T.C. (1994). The state, civil society and foreign actors: The politics of Philippine industrialization. Contemporary Southeast Asia, 16(2), 157-177.

Rosner, R.L. (2003). Earnings manipulation in failing firms. Contemporary Accounting Research, 20(2), 361-408. http://dx.doi.org/10.1506/8EVN9KRB-3AE4-EE81

Roychowdhury, S. (2006). Earnings management through real activities manipulation. Journal of Accounting and Economics, 42(3), 335-370. http://dx.doi. org/10.1016/j.jacceco.2006.01.002

Salleh, H. (1999). Development and the politics of social stability in Malaysia. Southeast Asian Affairs. Singapore: Institute of Southeast Asian Studies.

Sato, Y. (1993). The Salim Group in Indonesia: The development and behaviour of the largest conglomerate in Southeast Asia. The Developing Economies, 31(4), 408-441. http://dx.doi.org/10.1111/j.1746-1049.1993.tb00033.x

Saudagaran, S.M., \& Diga, J.G. (2000). The institutional environment of financial reporting in ASEAN. The International Journal of Accounting, 35(1), 1-26. http:/ / dx.doi.org/10.1016/S0020-7063(99)00046-1

Selahudin, N.F., Zakaria, N.B., \& Mohd. Sanusi, Z. (2014). Remodelling earnings management with the appearance of leverage, financial distress and free cash flow: Malaysia and Thailand evidences. Journal of Applied Sciences, 14(21), 2,644-2,661. http:/ / dx.doi.org/10.3923/jas.2014.2644.2661

Semkow, B. (1995). Chinese corporate governance in the ASEAN countries - Some implications for Europe and European firms (Working paper). Hong Kong: 
Hong Kong University of Science and Technology \& France: INSEAD Euro-Asia Centre.

Senate Economic Planning Office of the Philippines. (2006). A profile of selected Philippine Government-Owned and -Controlled Corporations (GOCC). Pasar City, Philippines. Retrieved from https://www.senate.gov.ph

Shayan Nia, M., Sinnadurai, P., Mohd-Sanusi, Z., \& Hermawan, A. (2017). How efficient ownership structure monitors income manipulation? Evidence of real earnings management among Malaysian firms. Research in International Business and Finance, 41(October), 54-66. http://dx.doi.org/10.1016/j. ribaf.2017.04.013

Shleifer, A., \& Vishny, R.W. (1997). A survey of corporate governance. Journal of Finance 52(2), 737-783. http://dx.doi.org/10.1111/j.1540-6261.1997. tb04820.x

Siddiquee, N.A. (2002). Administrative reform in Malaysia: Recent trends and developments. Asian Journal of Political Science, 10(1), 105-130. http:// dx.doi.org/10.1080/02185370208434204

Siddiquee, N.A. (2006). Public management reform in Malaysia: Recent initiatives and experiences. International Journal of Public Sector Management, 19(4), 339-358. http://dx.doi.org/10.1108/09513550610669185

Sinnadurai, P. (2016). Unique determinants of abnormal earnings growth in Malaysia. Pacific Accounting Review, 28(1), 16-37. http://dx.doi.org/ 10.1108/PAR-09-2013-0093

Sta Ana, F. (1998). Privatisation and government reform in the Philippines. International Journal of Urban Sciences, 2(2), 160-170. http:/ /dx.doi.org/10.1080/ 12265934.1998.9693420

Tabalujan, B.S. (2002). Family capitalism and corporate governance of familycontrolled listed companies in Indonesia. UNSW Law Journal, 25(2), 486514.

Tan, L. (2004). Chinese schools in Malaysia: A case of cultural resilience. In K.H. Lee \& C.B. Tan (Eds.), The Chinese in Malaysia (2nd impression, pp. 228254). Shah Alam, Malaysia: Oxford University Press.

Tee, C.M., Gul, F.A., Foo, Y-B., \& Teh, C.G. (2017). Institutional monitoring, political connections and audit fees: Evidence from Malaysian firms. International Journal of Auditing, 21(2), 164-176. http://dx.doi.org/10.1111/ ijau.12086

Vafeas, N. (2005). Audit Committees, boards, and the quality of reported earnings. Contemporary Accounting Research, 22(4), 1,093-1,122. http://dx.doi. org/10.1506/1QYN-2RFQ-FKYX-XP84

Vithiatharan, V., \& Gomez, E.T. (2014). Politics, economic crises and corporate governance reforms: Regulatory capture in Malaysia. Journal of Contemporary Asia, 44(4), 599-615. http:/ / dx.doi.org/10.1080/00472336.2014.923634

Wang, D. (2006). Founding family ownership and earnings quality. Journal of Accounting Research, 44(3), 619-656. http://dx.doi.org/10.1111/j.1475-679X. 2006.00213.x 
Warburton, E. (2016). Jokowi and the New Developmentalism. Bulletin of Indonesian Economic Studies, 52(3), 297-320. http://dx.doi.org/10.1080/000 74918.2016.1249262

Wickberg, E. (1964). The Chinese Mestizo in Philippine history. Journal of Southeast Asian History, 5(1), 62-100. http://dx.doi.org/10.1017/S021778 1100002222

Wu, Y., Gaunt, C., \& Gray, S. (2010). A comparison of alternative bankruptcy prediction models. Journal of Contemporary Accounting and Economics, 6(1), 34-45. http://dx.doi.org/10.1016/j.jcae.2010.04.002

Wurfel, D. (1999). Convergence and divergence amidst democratization and economic crisis: Thailand and the Philippines compared. Philippine Political Science Journal, 20(43), 1-44. http://dx.doi.org/10.1080/01154451.1999. 9754203

Yang, J.S., \& Krishnan, J. (2005). Audit committees and quarterly earnings management. International Journal of Auditing, 9(3), 201-219. http://dx.doi. org/10.1111/j.1099-1123.2005.00278.x

Yap, B.C-F., Yong, D.G-F., \& Poon, W-C. (2010). How well do financial ratios and multiple discriminant analysis predict company failures in Malaysia? International Research Journal of Finance and Economics, 54(13), 166-175.

Yermack, D. (2006). Flights of fancy: Corporate jets, CEO perquisites and inferior shareholder returns. Journal of Financial Economics, 80(1), 211-242. http:// dx.doi.org/10.1016/j.jfineco.2005.05.002

Yeung, H.W.C. (2006). Change and continuity in Southeast Asian ethnic Chinese business. Asia Pacific Journal of Management, 23(3), 229-254. http://dx.doi. org/10.1007/s10490-006-9007-2

Zang, A.Y. (2012). Evidence on the trade-off between real activities manipulation and accruals-based earnings management. Accounting Review, 87(2), 675703. http://dx.doi.org/10.2308/accr-10196

Zmijewski, M.E. (1984). Methodological issues related to the estimation of financial distress prediction models. Journal of Accounting Research, 22(Supplement), 59-82. http://dx.doi.org/10.2307/2490859 
